\title{
Spatial and long-term changes in the functional and structural phytoplankton communities along the French Atlantic coast
}

\author{
Valérie David ${ }^{a, 1, *}$, Mireille Ryckaert ${ }^{\mathrm{b}}$, Mikhail Karpytchev ${ }^{\mathrm{a}}$, Cédric Bacher ${ }^{\mathrm{c}}$, Vanessa Arnaudeau ${ }^{\mathrm{a}, \mathrm{b}}$, \\ Nadia Vidal ${ }^{\mathrm{a}, \mathrm{b}}$, Danièle Maurer ${ }^{\mathrm{d}}$, Nathalie Niquil ${ }^{\mathrm{a}}$
}

\footnotetext{
a Littoral Environnement et Sociétés (LIENSs), UMR 7266 CNRS-Université de La Rochelle, Institut du Littoral et de l'Environnement, 2 Rue Olympe de Gouges, 17042 La Rochelle Cedex 01, France

${ }^{\mathrm{b}}$ IFREMER, Place Gaby Coll, BP 7, 17137 L'Houmeau, France

c IFREMER, BP 70, 29280 Plouzané, France

'IFREMER, Quai du Commandant Silhouette, 33120 Arcachon, France

${ }^{1}$ Present address: Station marine d'Arcachon UMR EPOC 5805 CNRS-Université Bordeaux 1, 2 rue du Prof. Jolyet, 33120 Arcachon, France.
}

\author{
*: Corresponding author : Valérie David, Tel . +33 (0)5 56223900 ;Fax. +33 (0)5 56835104 \\ email address : v.david@epoc.u-bordeaux1.fr
}

\begin{abstract}
:
Spatial and interannual variations of phytoplankton diversity were characterized along the French Atlantic Coast in relation to physical factors and large-scale climatic indices using phytoplankton surveys conducted from 1993 to 2010 in four geographical areas. This study relates phytoplankton diversity to oyster recruitment success by comparing a 'specific' versus a 'functional' diversity approach. Functional diversity was represented by functional groups of different phytoplanktonic functional traits (size, shape, toxicity), relevant for oyster feeding during growth, reproduction and larval development. Phytoplankton diversity patterns along the French Atlantic coast corresponded to a geographical distribution mainly driven by a latitudinal gradient and hydrodynamic features as confirmed by the functional characteristics of the indicator species recorded for each geographical area (C-S-R strategies of Reynolds, specific habitat). This geographical typology was less clear for functional diversity. Only few functional groups were explained by physical factors: the non-toxic small and solitary cells were in particular related to temperature, with high densities observed in the southern areas. Even if temporal variation was less important in explaining the phytoplankton diversity patterns, the main drivers explaining the interannual pattern were the large-scale climatic indices, mainly the Atlantic Multidecennal Oscillation. Functional groups were readily explained by climatic indices than species even if the relationships cannot be applied generally because of the non-linearity of the correlations (local and temporal variations). However, the potentially toxic, small and linear phytoplankton were anticorrelated to NAO. The functional approach thus brings constructive elements concerning the relationships between the prey assemblage of oysters and their physical drivers. Redundancy and co-inertia analyses appeared as complementary analyses in investigating phytoplankton pattern of variation, being particularly useful in analyzing geographical and temporal diversity fluctuation, respectively.
\end{abstract}

Keywords: phytoplankton ; long-term variation ; spatial variation ; climate ; Atlantic coast 


\section{Introduction}

Plankton plays a key role in the trophodynamics of aquatic ecosystems. Several planktonic taxa are important food source for pelagic or benthic species (fishes, mollusks) of economical interest (Baldwin and Newell, 1995; Beaugrand et al., 2003; Pasquaud et al., 2010). The trophic link is direct and generally ,specifice of a size, a form or a taxa. This specificity varies according to the presence and abundance of predator species. For example, larval oysters feed preferentially on smaller phytoplankton cells instead of bacteria, protozoa or dissolved particulate organic matter (Olson and Olson, 1989) whereas larval cods prefer one particular species of copepods due to its size and phenology (Munk, 1997). This narrow preypredator link is often restricted to a short period in the life stages of these species. It thus necessitates a perfect matching between prey and predator to allow the survival of predators (Beaugrand et al., 2003).

Plankton is also used as indicators of climatic changes since its quick response to hydroclimatic forcing in the pelagic trophic web (Beaugrand, 2005). Such responses are due to its short life span and its ability to produce resting stages (Guerrero and Rodriguez, 1998; McQuoid et al., 2002). Moreover, long-term changes had been recorded for different plankton compartments at different spatial scales and attributed to hydroclimatic variability at local, regional and global scale (Boyce et al., 2010), and meso- or macrozooplankton at local or regional scale (Beaugrand et al., 2002; Roemmich and McGowan, 1995). For both phyto- or zooplankton, such changes concern not only their respective biomass (Roemmich and McGowan, 1995) but also their biogeography (Beaugrand et al., 2002; Leterme et al., 2008), their phenology (Edwards et al., 2001) or some physiological features such as size or fecundity rate (David et al., 2007). Even if the decline of exploited fish or mollusks had classically been attributed to human activities (e.g. overfishing, climatic changes could thus have drastic consequences in the trophodynamics of aquatic food webs through bottom up or wasp-waist control (Griffiths et al., 2010; Richardson and Schoeman, 2004). They could alter the functioning of ecosystems, their resilience and the services they provide in synergism with other anthropogenic pressures (Goberville et al., 2010; Llope et al., 2011). Recent works have actually shown that climatic change may lead to large-scale redistribution of global catch potential for some exploited marine fishes and invertebrates (Cheung et al., 2010) and could cause the destruction of such species assemblages because of the alteration in habitat quality (Wilson et al., 2008) . However, the indirect link between climate change and exploited macrofauna through planktonic forms remains tenuous in the management of exploited marine 
species. A functional diversity approach, i.e. considering the species according specific functional traits in the ecosystem, could be particularly relevant to understand the relationship between prey and predator. Functional diversity is actually important for the understanding of ecosystem functioning as the number of functional groups are a more powerful determinant of processes than species richness (Downing and Leibold, 2002; Tilman et al., 1997). Such a functional approach has been criticized when used for planktonic models. Anderson (2005) underlined that the danger of trying to ,run before walk ${ }^{\text {ee }}$ because of the lack of ecological knowledge and thus the difficulties of aggregating diverse organisms into functional groups. However, this approach has been particularly useful to clearly understand the mechanisms in prey-predator relationships (Azemar et al. 2007; Pasquaud et al 2010) and thus highlight the consequences of the variability of prey assemblages on predator survival (Beaugrand et al., 2003). Azemar et al. (2007) and Pasquaud et al. (2010) used population characteristics of prey (growth rate, individual weight, and population biomass) to understand the feeding strategy of predators (generalist, specialist or opportunistic). Functional traits such as prey size or phenology have also been used to build an index for long-term monitoring of larval cod survival in the North Sea (Beaugrand et al., 2003).

Phytoplankton is the main food source for benthic filter-feeders such as oysters, mussels or cockles, which are of commercial interest (Robert, 2003). Growth and reproduction of the Pacific oyster, Crassostrea gigas, are clearly related to phytoplankton densities (Bourlès et al., 2009). Several economical problems related to decline of the oyster livestock have risen recently throughout the world and notably along the French Atlantic coast, For example (i) „abnormale mortalities ( $>30 \%$ of the population) of one-and two-year-old oyster during springsummer (Soletchnik et al., 2007) which seemed to be, at least partly, attributed to phytoplankton biomass (chl a concentrations), and (ii) weak settlement of oyster larvae particularly in 2002, 2005 and 2009 in Arcachon Bay and Marennes-Oléron Bay, the two main center of spat production in France. Oyster larval settlement depends on both (i) larval survival as meroplankton during their development and (ii) larval densities resulting from the reproductive effort of the adults. The latter could be related to phytoplankton availability for adults before the summer spawning (i.e. between February and June).

Global warming could induce noticeable taxonomic changes with a global shift from a diatom-based system to a more flagellate-based one (Leterme et al., 2008). It also contribute to the development of non-endemic species, including toxic species involve in harmful algal blooms (Penna et al., 2005).4 Such changes in phytoplankton species composition can induce changes in functional attributes of the communities (Beaugrand, 2005)). Actually, some 
112 features of phytoplankton, such as size and nutritional quality (Baldwin and Newell, 1995; Barillé et al., 1993), are especially important for the development and recruitment success of oyster larvae (Robert and Trintingnac, 1997). The long-term variability of phytoplankton diversity, both specific and functional, might thus be interesting in understanding the recruitment success of oyster larvae.

Phytoplankton communities have been described along the French Atlantic coast and two large areas have been distinguished based on specific diversity, according to the temporal variability patterns of microphytoplankton populations between 1992 and 2000 (English Channel and Bay of Biscay) and have been related to hydrodynamic features (Gailhard et al., 2003). However, spatial variability was considered so important in explaining the specific diversity patterns that it curtailed analysis of temporal variability. Finally, Beliaeff et al. (2001) highlighted the difficulty to distinguish site-specific seasonal variations of phytoplankton species from high between-year variations and attributed the latter to climate change.

The aim of the present study was to characterize the spatial and interannual variations of phytoplankton diversity along the French Atlantic coast in relation with physical factors and 127 large-scale climate indices. Both specific and functional diversities were considered. The 128 functional groups were assessed using phytoplankton functional traits based on their 129 availability to oyster feeding. 


\section{Material and methods}

\subsection{Study area}

Phytoplankton communities were studied in 4 geographical zones along the French Coast, namely North of Brittany (NB), South of Brittany (SB), the Pertuis Charentais area (PC) and the Arcachon Bay (AB) (see Figure 1). The data collected belong to the REPHY program and were extracted from the Ifremer Quadrige database. The REPHY aims are 1) to describe the spatio-temporal distribution of the different phytoplankton species along the French Coast and 2) to detect the occurrence of toxins-producing species, a public health hazard for shellfish consumption. Only 8 stations were selected of the 29 stations available in the REPHY database because of the lack of temporal synchronicity between station sampling over a long-term period.

All geographical areas have a temperate climate under oceanic influence characterized by mild winters (about $\left.10^{\circ} \mathrm{C}\right)$ and summers $\left(<23^{\circ} \mathrm{C}\right)$. Precipitation is high (about 700 $800 \mathrm{~mm} /$ year) with higher rainfall between October and January. All sites were also characterized by dominant West wind and semi diurnal tides.

The Arcachon Bay (AB) is a macrotidal coastal lagoon of $174 \mathrm{~km}^{2}$ connected to the Bay of Biscay by a narrow channel (2-3 km wide). In the inner lagoon, tidal channels $\left(41 \mathrm{~km}^{2}\right)$ penetrate between large intertidal areas $\left(115 \mathrm{~km}^{2}\right)$. Sixty percent of these tidal flats are covered by Zostera noltii meadows. Semi-diurnal tides enable important water exchanges with the adjacent oceanic waters. The input of fresh water is mainly by the Leyre River with an average annual river-flow of $19 \mathrm{~m}^{3} \mathrm{~s}^{-1}$. The sampling station, localized near the connecting channel with the Bay of Biscay, is slightly influenced by the river input. The Arcachon Bay is the greatest European spat production site for the Pacific oyster, Crassostrea gigas and a major center for oyster farming.

The Pertuis Charentais is a semi-diurnal macrotidal area located northward on the French Atlantic coast, largely characterized by a marine water influence and with a total surface area of $1300 \mathrm{~km}^{2}$ comprising $340 \mathrm{~km}^{2}$ of shallow (0-5 m depth) soft bottom areas located in the inner bays. It consists of two main straits; the Pertuis Breton on the North and the Pertuis d"eAntioche - Marennes-Oléron Bay on the South. Only small rivers flow into each strait: (i) in the Pertuis Breton, an average annual river-flow of $20 \mathrm{~m}^{3} \mathrm{~s}^{-1}$ from the Lay River, $25 \mathrm{~m}^{3} \mathrm{~s}^{-1}$ from the Sèvre-Niortaise River, (ii) in the Marennes-Oléron Bay $50 \mathrm{~m}^{3} \mathrm{~s}^{-1}$ from the Charente River, 1-2 $\mathrm{m}^{3} \mathrm{~s}^{-1}$ from the Seudre River (Durieux et al., 2010). The tidal range and currents allow the rapid renewal of marine water and a well-mixed environment, particularly in 
the shallower areas. However, water masses presented different residence time in both straits: about 30 days in the Pertuis Breton and 10 days in the Marennes-Oleron Bay. The Pertuis Charentais is the Europe"s largest production area for the Pacific oyster: with a standing stock of 125,000 tonnes and an annual production of 38,000 tonnes in 2001 (Goulletquer and Le Moine, 2002). Four stations were sampled in this bay: Eperon located in the Pertuis Breton, Le Cornard, Boyard and Auger in the Marennes-Oleron Bay. The two southern stations can also be influenced by Gironde estuary outputs.

The North and South of Brittany areas are also located near oyster farming areas (Soletchnik et al., 2007) even if production is low compared to Pertuis Charentais and Arcachon Bay. The Bay of Le Croisic is the main production site of the cockle, Cerastoderma edule in France of about 1200 tons a year (Rollo and Robin, 2010). It is located on the Atlantic Coast of France in the South of Brittany (SB). The main freshwater output is coming from the Loire River presenting an average annual river-flow of about $931 \mathrm{~m}^{3} \cdot \mathrm{s}^{-1}$.

The two Northern stations are located in the western part of the English Channel, in the western part of the North of Brittany (NB). The main river inputs are provided by small coastal rivers (the Arguenon River at the Saint-Cast station and the Le Trieux River at the Paimpol station). The average annual river-flow of both is $<5 \mathrm{~m}^{3} \mathrm{~s}^{-1}$.

\subsection{Presentation of the raw database}

Both environmental and biological data were available for stations over different time periods: (1) the NB stations (Saint-Cast and Paimpol) from April 1993 to march 2004, (2) the SB station (Le Croisic) and the 3 northern PC stations (Eperon, Le cornard and Boyard) from April 1993 to January 2010, (3) the southern PC station (Auger) and the AB station (Arcachon) from February 2003 to January 2010.

Sampling was conducted approximately every fortnight at each station. The phytoplankton was identified to the lowest taxonomic level possible and counted with an inverted microscope using the Utermöhl method (Utermohl, 1958): 358 taxa were identified over the eight stations. : The water temperature $\left({ }^{\circ} \mathrm{C}\right)$, salinity (PSU) and turbidity (NTU) were also measured during each sampling session at each station. Both phytoplankton and physical databases were recorded on 349 dates for both the NB stations, on 595 dates for the SB station and the 3 PC stations and on 214 dates for the southern PC station and the AB station.

Two large-scale hydro-climatic indices were considered during this sampling period (1993 to 2010) because of their importance in the studied area (Beaugrand, 2009; Goberville et al., 2010). The winter North Atlantic Oscillation (NAO) index (Hurrell, 1995) is a basin-scale 
alternation of atmospheric masses between the subtropical and the Arctic Atlantic (Dickson and Turrell, 2000). The Atlantic Multidecadal Oscillation (AMO) index is a large-scale oceanic phenomenon, the source of natural variability in the range of $0.4^{\circ} \mathrm{C}$ in many oceanic regions (Enfield et al., 2001). This index was downloaded from http://climexp.knmi.nl/ and was constructed from Extended Reconstruction SST (ERSST) data and averaged in the area of 25 to $60^{\circ} \mathrm{N}$ and 7 to $75^{\circ} \mathrm{W}$, minus regression (i.e. detrending is intended to remove the North Atlantic SST anomaly data from the analysis) on global mean temperature (National Climate Data Center, USA: NCDC).

\subsection{Data analysis}

All tests were performed with R software routines (R Development Core Team, 2008)

In the phytoplankton database, rare species were excluded using the abundance sorting method (Figure 2). This method, adapted from Ibanez et al. (1993), uses an index mixing species abundances and frequencies, retaining only the frequent and locally abundant taxa at least at one station (Roussel et al., 2010): 106 taxa were kept, i.e. 30\% of the total taxa richness, representing between 90 and $96 \%$ of the total abundances at each station.

Each series of taxa abundances, physical parameters and climatic indices were regularized for each station using a SPLINE function (package PASTECS for R) (Grosjean and Ibanez, 2002 ) in order to obtain regulated series with 24 dates per year, synchronized between stations (Figure 2). Consequently, the long-term series presented a similar number of values per year and could be subjected to numerical analyses (David et al., 2005). Both phytoplankton, physical factors and climatic indices represented by 268 dates for NB stations, 409 dates for the SB station and 3 for the PC stations and 168 dates for the southern PC station and the AB station.

Phytoplankton taxa were classified according to functional traits based upon their availability to oyster feeding. The factors conditioning the phytoplankton availability for oyster feeding include their availability for ingestion - size, shape and availability in the water column-, and for digestibility -cell wall structures and biochemical composition (Brown et al., 1998). The functional traits that have been used in this study were thus: (i) the size of an individual cell, (ii) the individual or colonial shape, (iii) the potential toxicity.

- the size of an individual cell: only particles measuring between 5 and $100 \mu \mathrm{m}$ are efficiently retained by pacific oysters (Barillé et al., 1993). Moreover, larvae preferentially feed on

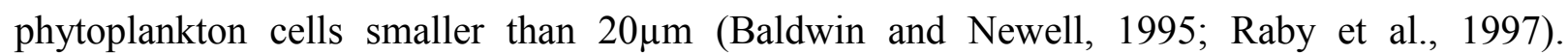
Consequently, phytoplankton taxa were classified according to 3 size-classes: small size (T1, 
equivalent spherical diameter (ESD) between 5 and $20 \mu \mathrm{m}$ ) consumed preferentially by oyster larvae, juveniles and adults; median size ESD (T2, between 20 and $100 \mu \mathrm{m}$ ) used at least by adults, whereas large size ESD ( $>20 \mu \mathrm{m}, \mathrm{T} 3)$ are consumed to a lesser extent by oysters.

- the shape: this trait can influence the size perception by the oyster. Colonial taxa (versus solitary taxa) would be seen as larger than their individual ESD size, while a "linear" colony would be more easily consumed than an ovoid colony. Phytoplankton taxa were thus classified according to 3 shapes: (1) solitary cells (s) and (2) a linear colony of cells (ln); both assumed to be consumed by oysters, and (3) other shapes.

The microphytoplankton data was thus separated into two databases: (1) a ,specific database ${ }^{e e}$ including the abundances of the 106 species for each station/date and (2) a „functional database" presenting the abundances of the 10 functional groups for each station/date. For each database, different diversity indices were calculated, namely species richness (number of taxa or functional groups), the Pielou evenness and the Shannon diversity indices (Gosselin, 2006; Washington, 1984).

Interannual variability of each variable (specific and functional diversity, physical factors and climatic indices) were extracted using moving averages with a step of 24 (24 data a year) for each station. The new series included trends and pluriannual cycles, seasonal variability being removed from the previous regularized series (David et al., 2005). Both diversity database were $\log$-transformed, i.e. $\log (x+1)$, to attain homogeneity of the variances and environmental factors (climatic indices and physical factors) were normalized.

The relationship between environmental parameters (physical factors and climate indices) and specific/ functional diversity were then analyzed on a database constituted of different twoway tables (i.e., diversity $v s$ environmental factors parameters) with spatial (eight stations) and temporal variations (from 1993 to 2010). Two types of two-table coupling methods, i.e. one derived from canonical analysis, redundancy analysis (RDA) (Wollenberg, 1977) and one coinertia analysis, partial triadic analysis (PTA) (Kroonenberg, 1989; Thioulouse et al., 2004) were used to elucidate patterns in both specific and functional diversity in relation with physical factors and climatic indices for all stations and time periods (package ade4 for R; Figure 2). The principle of both analyses is similar except that it is the covariance between the row coordinates of the two tables that are maximized in PTA, instead of the correlation in RDA (as other canonical analysis). An additional regression step is also added for RDA, ensuring that sampling scores are linear combinations of environmental variables. The use of these two complementary methods allowed to analyze a three-way table (diversity $\times$ environment $\times$ stations) over time 
(i) as a sequence of two-way tables (diversity $v s$ environment for each station), that is to say to search for interannual pattern that are stables among the stations using the PTA.

(ii) without considering stations independently and thus allowing to estimate the greater source of variability (spatial or temporal) in phytoplankton patterns.

\section{Step 1. Spatial versus temporal pattern in phytoplankton diversity.}

The redundancy analysis (RDA) was used on both specific and functional diversity to elucidate phytoplankton patterns in relation with physical factors and climatic indices for all stations and time periods (package ade4 for R; Figure 2). The significance of the eigenvalues and species-environment correlations of the five axes were determined by Monte Carlo tests (499 permutations; package vegan for R).

The various measures between geographical areas (NB, SB, PC and AB, „space'), time period (interannual variability, ,time') and interaction space $\times$ time were tested with a Two-way ANOVA for (1) physical factors, (2) total phytoplankton abundances, abundances of some characteristic groups of taxa or functional groups and (3) other diversity indices as richness, the Shannon-Weaver or the Simpson evenness indices for both taxonomic and functional diversity. Post-hoc comparison were inferred when $p<0.05$ (Figure 2). Time was separated in four periods corresponding to various large scale climate indices (from 1993 to 1995, from 1996 to 1998, from 2002 to 2007 and 1999, 2000-2001, 2008-2010).

The most characteristic taxa and functional groups of the different geographical areas were identified using the IndVal method developed by (Dufrêne and Legendre, 1997). This method consists in computing an indicator value (IndVal index) by taking into account both measures of fidelity and specificity. The indicator species assemblages can be obtained from any kind of cluster. The index for a given taxa is independent of the relative abundance of any other taxa and it is maximal when all individuals of a taxa are found in a single geographical area or when the taxa occurs in all geographical areas for that group.

\section{Step 2. Temporal variation of the phytoplankton related to physical factors and climatic} indices.

The partial triadic analysis (PTA) was used on both specific and functional diversity to elucidate phytoplankton patterns in relation with physical factors and climatic indices for all stations and time periods (package ade4 for R; Figure 2). Three PTA routines were used because all stations were not sampled over the same temporal periods: The first one on the 
298 whole period (from 1993 to 2010 ) was only available for the SB station, Eperon, Cornard and

1
299 Boyard for the PC area, the second one on the period 1993 to 2004 available for the 6 northern stations (NB and SB stations, Eperon, Le Cornard and Boyard for PC area) and the third PTA routine on the period from 2003 to 2010 available for the 6 southern stations (SB, PC and AB stations). 


\section{Results}

\subsection{Spatial versus temporal pattern in phytoplankton diversity}

The redundancy analysis explained significantly $47.2 \%$ of the total variance of the specific diversity (Monte Carlo permutation test, $\mathrm{p}=0.002$ ), with $42.5 \%$ of the total variance explained by the first 3 axes $(22.0 \%$ by the first axis, $13.4 \%$ by the second axis and $7.1 \%$ by the third axis). All these canonical axes and the explaining variables were significant (Monte Carlo permutation tests, $\mathrm{p}<0.01)$. The coefficients between the environmental variables and the ordination axes showed that temperature $(0.869)$ was the best explanatory variable on the first canonical axis (Figure 3A and 3D), followed by salinity (-0.723) and turbidity (0.651). Salinity was also well-represented on the second canonical axis (-0.636) and turbidity on the third canonical axis $(0.626)$

The RDA analysis explained significantly $34.3 \%$ of the total variance of the functional diversity (Monte Carlo permutation test, $\mathrm{p}=0.002$ ), with $30.6 \%$ of the total variance explained by the first 2 axes $(22.4 \%$ by the first axis and $8.2 \%$ by the second axis). All these canonical axes and the explaining variables were significant (Monte Carlo permutation tests, $\mathrm{p}<0.01$ ). The coefficients between the environmental variables and the ordination axes showed that salinity $(-0.800)$ and temperature $(0.772)$ (Figure 4A) were the best explanatory variables on the first canonical axis. AMO (-0.620) and turbidity (-0.565) were moderately represented on the second canonical axis. The coefficients between the functional groups and the ordination axes showed that $\mathrm{T} 1 \mathrm{~s}(0.833)$ and $\mathrm{T} 1(0.77)$ were highly correlated to the first axis, followed by T3 (0.687) and T2sTx (0.624; Figure 4C). All this functional groups were favored by high temperature and low salinity. Moreover, T2 seemed to be inversely correlated to turbidity on the second axis.

Consequently, the RDA showed a spatial discrimination of phytoplankton specific and functional diversity highly related to physical factors (temperature, salinity and turbidity) rather than a temporal pattern. The four geographical areas were well-distinguished on the third 3 axes of the taxonomic Redundancy Analysis. Biddulphia spp. and Dactyliosolen fragilissimus can be considered as opportunistic taxa and T2s and T2ln as opportunistic functional groups for all the geographical areas since they share high and comparable IndVal values at the highest hierarchical level (Figure 5A and 5B).

The North of Brittany zone (NB) was significantly characterized by the lowest temperature and turbidity compared to others zones (Two-way ANOVA, factor „spacee, 
$\mathrm{p}<0.001$ ). This area contained the lowest phytoplankton densities (Two-way ANOVA, factor „space $\left.{ }^{e e}, \mathrm{p}<0.05\right)$. This zone is also significantly characterized by the lowest abundances of T1s, T1ln, T1lnSpTx, T1, T2s and T2sTx (Two-way ANOVA, factor „,space ${ }^{e e} ; \mathrm{p}<0.001$ ). The lowest specific and functional richness (Two-way ANOVA, factor ,space ${ }^{e e}$ p $<0.001$ ). It is also characterized by the lowest abundances of freshwater and neritic species (Two-way ANOVA, factor ,,space $\left.{ }^{e e} ; \mathrm{p}<0.001\right)$. Five taxa reaching their highest IndVal values were considered as specialists of the NB: Guinardia striata, G. delicatula, Rhizosolenia styliformis and PseudoNitzchia delicatissima (Figure 5A).

Twenty-one taxa and six functional groups are reported as generalist of the Atlantic coast, the functional groups being T3, T2sTx, T1s, T1, T1lnSpTx and T1ln.

The South Brittany zone (SB) is significantly characterized by the lowest salinity (Twoway ANOVA, factor ,,space ${ }^{e e} ; \mathrm{p}<0.001$ ). It presented the highest phytoplankton densities (Twoway ANOVA, factor ,space $\left.{ }^{e e}, \mathrm{p}<0.05\right)$. Seven taxa can be considered as specialist of this geographical area - Heterocapsa triquetra, Leptocylindricus spp., Pediastrum spp., Cocconeis spp., Katodinium spp., Cerataulina spp., and Melosira spp.,. SB presented the highest abundances of T1s, T1ln, T2s, T2sTx, and T2 and T3, T1sTx and T2 being specialist functional groups of this area. SB presented the highest Shannon indices for functional groups (Two-way ANOVA, factor ,,space $\left.{ }^{e e} ; \mathrm{p}<0.001\right)$.

The Pertuis Charentais zone (PC) is significantly characterized by the highest temperature and turbidity (Two-way ANOVA, factor „space ; p<0.001). The lowest abundances of T2ln, evenness and Shannon indices for taxonomic and functional diversity and the highest abundances of T1ln, benthic species and specific richness were observed in this area (Two-way ANOVA, factor „space ${ }^{e e} ; \mathrm{p}<0.001$ ). A warm and high-turbidity taxon Actinoptychus spp. only reported in this area $(\mathrm{IndVal}=100)$ and two high-turbidity taxa Biddulphia paxilifer and Prorocentrum triestinum are specialist of this area.

The Arcachon bay zone (AB) is significantly characterized by the highest salinity and temperature (Two-way ANOVA, factor ,space $; p<0.001$ ). The lowest densities of T2, benthic species, functional evenness and Shannon indices and the highest densities of T1lnSpTx, T2sTx and T1, far neritic species, taxonomic richness and Shannon diversity were observed in this zone (Two-way ANOVA, factor „space ${ }^{e e} ; \mathrm{p}<0.05$ ). Eleven taxa are specialist of the Arcachon bay with 2 taxa only reported in this area (Palaeophalacroma spp. and Prorocentrum compressum). 


\subsubsection{Relation between climate and local phytoplankton communities}

Salinity, temperature and turbidity showed significant variations according to the period of time characterized by different values of NAO and AMO (Two-way ANOVA, factor ,time $\mathrm{p}<0.001)$. Globally, salinity and temperature were high when NAO and AMO were low. Moreover, this fluctuations over time were significantly different according to the geographical area for temperature and turbidity (Two-way ANOVA, factor ,,space $\times$,time ${ }^{e e} ; \mathrm{p}<0.01$ ). Total abundances of phytoplankton were not significant different according to time (Two-way ANOVA, factor , space $\left.^{e e} ; \mathrm{p}>0.05\right)$.

\section{Specific diversity}

Over the period 1993 to 2010 for the SB and the three northern stations of PC, the two first axes of the partial triadic analysis explained $89.7 \%$ of the total inertia, with the main information brought by the first axis $(66.6 \%)$. The first factorial plan of the compromise for the environmental variables showed that the large-scale climatic indices AMO was the best explanatory variable on this first axis (0.716) and the NAO on the second axis (0.956; Figure 6A). Temperature was also inversely correlated to AMO on the first axis (-0.560). The Fam. Naviculaceae was correlated to AMO (0.310 on the first axis) and Leptocylindricus danicus to NAO (0.379 on the second axis) on the first factorial plan for species (Figure 6C). Over the period 1993 to 2004 for the six northern stations, the two first axes of the PTA explained 96.9\% of the total inertia, the main information was brought by the first axis $(86.9 \%)$. The first factorial plan of the compromise for the environmental variables showed that the large-scale climatic indices AMO was the best explanatory variable on this first axis and the NAO on the second axis. In contrast, over the period 2003-2010, the first two axes explained $97.5 \%$ of the total inertia (88.2\% and 9.3\%, respectively) but both AMO and NAO were explained by the two axis. The same species, Naviculaceae and Leptocylindricus danicus were respectively correlated to AMO and NAO respectively on the first factorial plan for species for both analyses. Moreover, Pseudo-Nitzchia spp seemed also to be correlated to AMO for both analysis while Guinardia striata was negatively correlated to NAO for the second analysis.

Considering the first factorial plan of the compromise for the date points for the three PTA, all stations showed the same interannual evolution, namely (1) from negative values to positive values on the first axis corresponding to an increase of the AMO index and strong fluctuations over the second axis (associated to variations of the NAO index) from 1993 to 2001, and (2) low fluctuations over both axes from 2001 to 2006 and increasing values over the second axis (NAO) from 2006 to 2010 corresponding to an increase of the NAO index 
whereas AMO was high and stable. The same results were observed on the both other PTA (periods 1993-2001 and 2003-2010).

Dinoflagellate abundances were significantly higher for high AMO and NAO values (Two-way ANOVA, factor ,time,$p<0.001$ ) and species richness was greater for high AMO (Two-way ANOVA, factor ,time ${ }^{e e} ; \mathrm{p}<0.001$ ). These schemes were different between the geographical areas (Two-way ANOVA, factor ,,space ${ }^{\text {ee }} \times$,time ${ }^{e e} ; \mathrm{p}<0.01$ ). Marine species were also less abundant for high NAO and this was observed for all geographical areas (Two-way ANOVA, factor ,time $;$ p $>0.05$ )

\section{Functional diversity}

Over the period 1993 to 2010 for the SB and the three northern stations of PC, the two first axes of the partial triadic analysis explained $90.4 \%$ of the total inertia, with the main information brought by the first axis $(64.0 \%)$. The first factorial plan of the environmental variables was highly comparable to specific diversity, showing that the large-scale climatic indices AMO (0.785) was the best explanatory variable on this first axis and the NAO on the second axis (-0.903; Figure 6D). Temperature was also inversely correlated to AMO on the first axis (-0.545). T2 (-0.600), T1sTx (-0.411), T1 $\ln \mathrm{Tx}(-0.420)$ and $\mathrm{T} 3(-0.446)$ were anticorrelated to the first axis (and thus to AMO) and T1lnTx to the second axis (to NAO) on the first factorial plan for species (Figure 6F). Over the period 1993 to 2004 for the six northern stations, the two first axes of the PTA explained $97.1 \%$ of the total inertia, with the main information brought by the first axis $(83.0 \%)$. The first factorial plan of the environmental variables was highly comparable to specific diversity, showing that the large-scale climatic indices AMO was the best explanatory variable on this first axis and the NAO on the second axis. In contrast, from 2003 to 2010, the two first axes of the second PTA explained 98.9\% of the total inertia (59.2 and 49.7\%, for axis 1 and 2 respectively) but both AMO and NAO are well explained by the two axes as for specific diversity and opposed along the first axis. T1sTx were highly anticorrelated to AMO for both analysis whereas $\mathrm{T} 1 \ln \mathrm{Tx}$ was only correlated to NAO for the second analysis (Figure 6F).

Considering the first factorial plan of the compromise for the date points for both PTA, all stations showed the same interannual evolution, the same as for specific diversity. The interstructure tables showed globally the same differences inter-stations than for specific diversity.

$\mathrm{T} 1 \mathrm{~S}, \mathrm{~T} 1 \ln \mathrm{Tx}, \mathrm{T} 1 \ln , \mathrm{T} 2 \mathrm{sTx}$ were significantly higher for high NAO values and T2 were significantly higher for high AMO (Two-way ANOVA, factor ,time ${ }^{e e}$ p $<0.001$ ). Only T1lnTx 
434 presented the same variations whatever the geographical area considered (Two-way ANOVA, 1435 factor, space ${ }^{e e} \times$, ,time
3

3436

4

5

6

7

8

9

10

11

12

13

14

15

16

17

18

19

20

21

22

23

24

25

26

27

28

29

30

31

32

33

34

35

36

37

38

39

40

41

42

43

44

45

46

47

48

49

50

51

52

53

54

55

56

57

58

59

60

61

62

63

64

65 


\section{Discussion}

Among the functional groups defined according to the functional diversity approach, at least 2 can be highly exploited by oyster and thus influenced their growth, reproduction and recruitment. Food availability is actually a key factor for oyster recruitment even if previous works have shown that temperature highly influences larval growth and settling of the Pacific oyster during in vitro experiments (His et al., 1989; Scholtz et al., 1984). Moreover, previous works had shown food quality is much more important than food quantity for the recruitment success and that the factors conditioning the phytoplankton characteristics conducive for consumption by oyster adults and juveniles include their availability for ingestion (size, shape and quantity), and for digestibility (cell wall structures and biochemical composition (Barillé et al., 2003; Barillé et al., 1997; Brown et al., 1998). Oyster larvae are also able to actively select their prey according to their size and biochemical composition (Baldwin and Newell, 1995; Raby et al., 1997; Rico-Villa et al., 2006). Larvae prefer smaller phytoplankton cells to other prey in such as bacteria, and dissolved organic matter (Baldwin et al., 1989; Olson and Olson, 1989)).

Moreover, small but potentially toxic cell (T1sTx) might be highly damaging for oyster recruitment. This functional group is mainly represented by the abundances of two dinoflagellates, Karlodinium spp. and Karenia mikimotoi (about 55\% and $31 \%$ of the abundances of the functional group, respectively). The first one, Karlodinium spp., is usually found in highly nutrient-enriched eutrophic conditions, and clearly benefit from a combination of abiotic factors (excessive nutrients and low turbulence) and biotic factors (low grazing pressure and good prey availability (Hall et al., 2008): the presence of nano-planktonic cryptophytes is indeed a key factor driving the formation of toxic Karlodinium blooms, which are able of mixotrophic nutrition (Adolf et al., 2008). Even if cryptophytes were not recorded in this study because they were not counted for at all eight stations, this factor could explain that Karlodinium spp are extremely localized on only 2 stations of the Pertuis Charentais area and sporadically observed in Arcachon Bay. The second species, Karenia mikimotoi is a cosmopolitan species. Toxic blooms of K. mikimotoi is frequently recorded worldwide (eastern North Atlantic, Japan, Europe, Australia, South America, North Africa and China) (Zhang et al., 2009) suggesting less environmental requirements than Karlodinium spp.. Blooms of both species are commonly associated with shellfish mortality through toxin production inducing growth inhibition and the disruption of critical larval processes (Leverone et al., 2006; Zhang et 
al., 2009). Both dinoflagellates are marine species typical of the continental shelf region and benefiting from low turbulence. Blooms are observed during summer and fall when a thermal stratification appeared (Smayda and Reynolds, 2001).

The functional group T1sTx did not show any significant variation in abundances between the four geographical areas even though its species diversity is highly variable. Karenia mikimotoi is the common species in the four geographical areas, constituting at least $22 \%$ of the functional groups in terms of numbers. This species is the sole component of T1sTx for the northern area (the North of Brittany) and its abundance was low at the PC stations. However, the dominant species was Karlodinium spp. at 2 stations of the Pertuis Charentais and Prorocentrum spp., particularly P. minimum in the Arcachon Bay. The latter is a common, neritic, bloom-forming dinoflagellate, widely distributed geographically in temperate and subtropical estuarine and coastal environments (Heil et al., 2005; Wikfors, 2005). Prorocentrum effects on oysters include poor larval development, tissue pathologies and systemic immune responses (Wikfors, 2005). Its blooms generally occur under conditions of high temperatures and incident irradiances and low to moderate salinities in eutrophic coastal and estuarine environments even if they have been found under widely varying salinities and temperatures (Heil et al., 2005). Moreover, Karlodinium spp. and Prorocentrum spp. appeared as specialist indicator species for the Pertuis Charentais and the Arcachon Bay areas respectively. Heterosigma akashiwo is another species constituting the toxic functional groups but with weak abundances, appearing in contrast as a generalist species of the French Atlantic coast (the three southern areas). The specific composition of small toxic phytoplankton is thus different between the 2 geographical areas presenting a spat production (Pertuis Charentais and Arcachon Bay) even if their mean abundances were not significantly different.

\subsection{How to analyze spatial versus temporal variation of phytoplankton communities?}

The RDA analyzed a three-way table (diversity $\times$ environment $\times$ stations) over time without introducing a spatial discrimination in the analysis: temporal (through „date') and spatial (through „stations ${ }^{(e)}$ fluctuations were thus considered equally before calculations. Results clearly showed a spatial discrimination of phytoplankton diversity highly related to physical factors (temperature, salinity and turbidity) rather than a temporal pattern. This means that more differences are observed in phytoplankton communities between geographical areas than over the 17 years sampling (1993 to 2010) at each station. Consequently, diversity pattern 
502 of phytoplankton along the French Atlantic coast was mainly driven by geographical features at the mesoscale dimension.

However, the use of partial triadic analysis (PTA) enabled to elucidate the temporal fluctuations of phytoplankton communities over the 17-years period. The factors explaining this temporal pattern were different from those explaining spatial variation, i.e. climate indices versus physical factors. The intention of such and analysis is actually to consider a three-way table (diversity $\times$ environment $\times$ stations) over time as a sequence of twoway tables (diversity $\times$ environment for each station). It thus established an intra-station pattern of variation, proposing a compromise for all stations and stating how much each station is closer than this compromise.

Consequently, RDA and PTA might be complementary analysis in investigating phytoplankton pattern of variation. PTA has been particularly useful in this work in analyzing interannual fluctuations since RDA highlighted the geographical pattern of variation. However, the use of both RDA and PTA would have been useless if the pattern analyzed by the RDA would be the same as the PTA, that is to say the intra-station one. Moreover, the main drawback that could limit the use of a PTA is that this statistical method needs the same number of observations by sequence (i.e. the same number of date for each station in our study), making the RDA more accessible.

\subsection{Geographical typology of phytoplankton diversity}

The pattern of specific diversity corresponded to the geographical distribution of phytoplankton communities. Temperature correlated the best on the first axis of the redundancy analysis, showing a latitudinal decreasing gradient between North and South areas. Salinity was also important in discriminating the four areas according to the relative importance of marine versus continental influences. Three zones were identified:

- The North of Brittany zone (NB), localized in the Southern East part of the English Channel, and was characterized by low temperatures and turbidities.

- The South Brittany (SB) and the Pertuis Charentais (PC) zones, localized in the coastal zone of the Bay of Biscay, were systems with low salinities and high turbidities; the PC zone a little more warmer, salty and turbid than the SB zone.

- The Arcachon Bay (AB) occupied an intermediate position between these two areas (SB and PC), because of its high salinity and low turbidity. 
The geographical typology of microphytoplankton in the English Channel and Bay of Biscay was previously recorded by (Gailhard et al., 2003), but without any consideration of physical factors. This biogeographical typology was established on 17 stations (REPHY network) distributed along the French coast (English Channel, Bay of Biscay and Mediterranean coast) using a co-inertia analysis (STATIS method). Her typology did not highlight the distinctiveness of the Arcachon Bay even if this station seemed to be isolated from the Northern stations of the Bay-of-Biscay on the interstructure analysis (Gailhard et al., 2003)).

Even if such geographical typology was mainly explained by temperature, only few species showed a clear gradient between the Northern (and colder) area and the southern (and warmer) area. Only seven species were present in the four geographical areas with a decreasing Indval from South to North for four of them (Dictyocha spp., Nitzchia longissima, Odontella regia and Thalassionema nitzchioides) and inversely for Guinardia delicatula, Lauderia spp., and Licmophora spp. Such latitudinal increasing or decreasing gradient of species densities would clearly suggest a biogeographical distribution subject to temperature. Thalassionema nitzchioides preferred warm temperature which explain its decreasing northward gradient (optimum at $20^{\circ} \mathrm{C}$; (Karentz and Smayda, 1984). Moreover, some species are specialist for the intermediate areas such as Actinoptychus for PC or Heterocapsa triquetra for SB. Latitude thus appear not to play a role in phytoplankton distribution.

Gaillard et al. (2003) attributed the geographical typology concerning phytoplankton diversity to the hydrodynamic characteristics of each area and were of the opinion that local influences such as differences in nutrient input were of secondary importance. For example, Gaillard et al. (2003) argued that the phytoplankton community of the English channel was dominated by diatoms whereas dinoflagellates were more prevalent in the Bay of Biscay. The diatoms/dinoflagellates dominance had historically been related to the physical properties of the water column (Estrada et al., 1999; Kaneta et al., 1985), according to the „Margalef Mandala ${ }^{e e}$ model. The latter described a species succession in phytoplankton assemblages in which diatoms dominate periods of mixing and high nutrient concentrations (r-strategists) and dinoflagellates prevail under oligotrophic and stratified conditions as K-strategists (Margalef, 1978). High mixing rates would inhibit dinoflagellate growth through physiological damaging and behavioral changes, whereas diatoms would be less sensitive to mixing (Thomas and Gibson, 1990).

However, recent works considered that the „Margalef Mandala"e model was over restrictive because of the probable independence between mixing and nutrient availability. 
567 Reynolds et al. (2002) proposed a more complex phytoplankton classification system based on

\section{8} the species tolerances to different degrees of mixing and nutrient availability. The surface/volume $(\mathrm{S} / \mathrm{V})$ ratio and maximum linear dimension were used to group the species in three strategies $(\mathrm{C}-\mathrm{S}-\mathrm{R})$ rather than the previous two $(\mathrm{r}-\mathrm{K})$ proposed in the „Margalef Mandala ${ }^{e e}$ model. The $\mathrm{C}$-strategists are small and fast-growing species dominating in stratified waters with high nutrient levels. The R-strategists are characterized by high a $\mathrm{S} / \mathrm{V}$ ratio that would allow them to survive under high mixing conditions, but at high nutrient concentrations, while the S-strategists would be large and slow-growing species, dominating in oligotrophic waters and developing mixotrophy or vertical migration to obtain nutrients. This Reynolds scheme has been applied to marine dinoflagellates (Smayda and Reynolds, 2001; Smayda and Reynolds, 2003) and diatoms ((Alves-de-Souza et al., 2008). Dinoflagellate species were distributed among the three strategies but diatoms were recognized as R-strategists (except for Coscinodiscus spp.). In spite of their R-strategy, diatoms are not a homogeneous group in their ecological responses and they can be classified in different functional groups, reminiscent of the r-K strategies of Margalef (1978), correlated mainly to a gradient of N:Si ratio (Alves-deSouza et al., 2008)..

We thus tried to relate the geographical typology of microphytoplankton observed along the Atlantic coast to different functional traits of the species: (i) C-S-R and r-K strategies to the species behavior to mixing and nutrient availability; (ii) their preferred habitat (marine versus estuarine versus freshwater); (iii) their planktonic versus benthic features.

- The North of Brittany, and more generally the English Channel coasts is characterized by a very high marine (versus continental) influence compared to the southern areas. This is due to low river inputs and very strong tidal currents. The latter are important physical forcing vectors leading to a high vertical mixing all year round (Gailhard et al., 2003; Ryckaert et al., 1983). The specific diversity of phytoplankton corroborated such an assumption since (i) NB had the lowest densities of dinoflagellates and (ii) the specialist species recorded for NB were only R-strategist diatoms adapted to mixing: Among the diatoms, one r-strategist (Pseudonitzchia delicatissima), which favor high mixing, was also recorded as a specialist species in NB (Alves-de-Souza et al., 2008). However, none of these species was typical specialist of this area since they have also been recorded in the southern areas. Moreover, this diatom dominance was not associated with a high species-rich pool in contrast with a dinoflagellate dominance that more likely develop monospecific blooms as suggested by (Smayda and Reynolds, 2003).

- The two northern areas localized on the coast of the Bay of Biscay (SB and PC) are characterized by a high continental influence since they are submitted to high river inputs 
601 (Loire, Gironde, Charente) and lower tidal currents than in the English Channel. The hydrodynamic circulation is thus mainly controlled by winds, favoring the freshwater dispersion offshore. This haline stratification combined with an increase in luminosity caused a vertical stratification during summer (Lazure and Jegou, 1998) enhancing phytoplankton blooms (Labry et al., 2001). As for the North of Brittany, this hydrodynamic feature is also associated with the specific diversity of microphytoplankton. The highest mean density of dinoflagellate was actually recorded for both areas and generalist species of the Bay of Biscay were predominantly constituted by dinoflagellates in contrast with the specialist species of the English Channel. Moreover, the dinoflagellates Heterocapsa triquetra, Katodinium spp. (SB) and Karlodinium spp. (PC). Heterocapsa triquetra, Katodinium spp. (SB) and Karlodinium spp. (PC). were recorded as specialist species in both areas as C-strategists according to (Smayda and Reynolds, 2001). Both areas are also characterized by (i) freshwater specialist species (Olenina et al., 2006): Pediastrum spp., Melosira spp. (SB) and Bacillaria Paxillifer (PC), and (ii) specialist benthic and tychopelagic species (Jouenne et al., 2007; Olenina et al., 2006), namely Synedra spp. as generalist species of the Bay of Biscay and Fragilariaceae, Naviculaceae, Actinoptychus, Bacillaria paxillifer, Rhaphoneis as specialist species for PC, pointing to benthic resuspension through turbulence induced by the high river discharge and the wind-induced hydrodynamic features (Alpine and Cloern, 1992). The main difference observed between the two areas is the relative importance of freshwater and benthic organisms. The low saline SB area contained more freshwater specialist species and abundances whereas the highly turbid PC area contained a high number of benthic specialist species and high abundances. In this system, microphytobenthos is a great source of primary production through resuspension of algae due to the relative importance of the mudflat areas (Guarini et al., 2008).

The great connectivity with both marine, freshwater and benthic habitat can explain the high specific richness of the Pertuis Charentais. The oceanic interface is known to be an important source of diversity for phytoplankton due to species dispersion and immigration caused by hydrodynamic processes (Cloern and Dufford, 2005). On the other hand, the sporadic contribution of freshwater and benthic species compared to marine species could explain the low Pielou equitability and Shannon indices for this area.

- The low continental inputs by the Leyre River and the important water exchanges with the adjacent oceanic waters in Arcachon Bay provide hydrodynamic conditions similar to the English Channel (Glé et al., 2008) in spite of their southern localization on the Bay of Biscay. The vertical mixing prevents the summer stratification and thus limits dinoflagellate proliferation. North of Brittany specialist species are mostly constituted by R-strategist favored 
635 by high mixing: diatoms (Proboscia alata, Cerataulina pelagica), notably r-strategist

\subsection{Interannual variability of phytoplanktonic communities} a latitudinal gradient of temperature. The combination of tools as the IndVal method (Dufrêne allowed an understanding of the phytoplankton communities observed in each area. cells are among the functional group might be important to the recruitment success of oysters. The high positive correlation with temperature and negative with salinity could explain why the 2 southern areas are the sole site of oyster spat production in France. levels ((Smayda and Reynolds, 2001; Smayda and Reynolds, 2003). In the Pertuis Charentais, Dinophysis blooms are actually favored inside the bay during summer and fall when a thermal stratification appeared and nutrient are highly limiting (Delmas et al., 1992). Such conditions seemed be favored during warmer years. highly related to the physical parameters temperature, salinity and turbidity and mainly driven by the hydrodynamic features of each area such as mixing and nutrient availability, and not by and Legendre, 1997) associated to the functional traits of the indicator species based on CSR strategies identified by (Smayda and Reynolds, 2001) and (Alves-de-Souza et al., 2008) for marine diatoms and dinoflagellates, the preferential habitat and specific indices of diversity

Contrary to specific diversity, the geographical typology was not so clear for the functional diversity based on the oyster requirement for food. The small, solitary and non toxic

Concerning the potential toxic species, only the large forms of Dinophysis spp (D. caudata and D. acuminata) (D. caudata and D. acuminata). seemed to be related to temperature. These species occurred as generalist species in the Bay of Biscay occurring in low-nutrient and highly stratified habitats with toxic effects occurring at very low population 
Climatic indices (versus local physical factors) were the main drivers explaining the interannual pattern of phytoplankton communities along the French Atlantic coast. These results suggest that, locally, phytoplankton communities were affected by large-scale climate variability between 1993 and 2010. Changes in phytoplankton biomass at local, regional and global scales had previously been linked to climate forcing: interannual to decadal variations were strongly correlated with basin-scale climate indices, whereas long-term declining trend was related to increasing sea surface temperatures (Boyce et al., 2010). The climate effect on phytoplankton is indirect and caused by changes in hydrological conditions. For example, the interannual change of the phytoplankton biomass over the whole Northeast Atlantic had been attributed to increasing phytoplankton metabolic rates due to higher temperatures in cooler regions and to a decrease in nutrient supply leading to a biomass decrease in warmer regions (Doney, 2006; Richardson and Schoeman, 2004). Along the French Atlantic Coast, regional climate also influences European coastal systems modifying hydrological (physical and chemical) parameters (Goberville et al., 2010): This effect has been attributed to temperature, local atmospheric and ocean circulation changes. Such climatic effect had also being detected in chl $a$ used as an index of the phytoplankton biomass (Goberville et al., 2010).

Along the French Atlantic coast, both regional hydro-climatic and coastal changes were influenced by NHT (Northern Hemisphere Temperature anomalies), a large-scale climatological index, but the correlation was also significant with the Atlantic Multidecennal Oscillation (AMO (Goberville et al., 2010)). In our study, phytoplankton communities seemed to be related mostly to AMO than to NAO (first axis of the PTA). This suggests a high impact of climate through temperature instead of local atmospheric or circulation changes on phytoplankton communities. Previous works had actually established positive correlations between NHT and SST (Sea surface temperatures anomalies) stronger than with NAO in the eastern part of the North Atlantic, around the British Isles and the North Sea (Beaugrand and Reid, 2003). Moreover, AMO is an index constructed from Extended Reconstruction SST (ERSST), with temperature as the NHT index. SST appears as the master parameter governing the changes in the coastal environment (Beaugrand, 2009). On the contrary, the NAO measures a basin-scale alternation of atmospheric masses between the subtropical and the Arctic Atlantic (Dickson and Turrell, 2000). The low influence of the NAO compared with AMO could be attributed to a modest influence of atmospheric change on the local climatological parameters (Beaugrand and Reid, 2003).

However, the NAO seemed to drive interannual variation of phytoplankton communities from 2006 to 2010. This corresponded to a time period during which AMO 
variations were very weak. Such anomalies in the relationship between large scale climatic indices and biological compartments had yet been observed. (Fromentin and Planque (1996) reported a breaking down after 1996 in the strong negative correlation between NAO and the abundance of the copepod Calanus finmarchicus in the North Sea. The effect of climate depended upon the intensity of the climate anomalies. Only substantial negative or positive forcings were related to changes in the state of the coastal systems, while moderate forcing had no effect (Carpenter and Brock, 2006; Goberville et al., 2010). Consequently, the strength of the correlation between climate and hydrological or biological factors may vary locally and temporally (e.g. non-linearity of the correlation).

Besides the temporally change in the strength of correlation between AMO and phytoplankton communities, spatial variations have been pointed out. First, the strength and even the direction of the relationships between taxa or functional groups and AMO or NAO varied according the geographical areas. Moreover, the interannual variation of phytoplankton was clearly explained by AMO for both the South Brittany area and the Pertuis Charentais, butd was not for the North of Brittany and the Arcachon Bay. The effect of SST in the water column could increase the vertical stratification in the coastal regions, except for areas where mixing by tidal currents is intense and limits stratification (Goberville et al., 2010). The AMO effect was thus masked in the the North of Brittany and the Arcachon Bay zones. This assumption seemed to be confirmed by the positive correlation between AMO and Pseudonitzchia spp. which are flourish under stratified conditions (Alves-de-Souza et al., 2008). High AMO also favored benthic species (Jouenne et al., 2007) as Naviculaceae, a specialist taxa of Pertuis charentais. This confirmed that resuspension is induced by high river discharge, causing stratification in the dilution plume of rivers. Highly significant correlations had also been established between AMO and turbidity at most of the PC stations.

Toxic functional groups seemed to be particularly related to large-scale climatic indices because (1) small and solitary cells (T1sTx) were anticorrelated to AMO when the effect of this index is high (from 1993 to 2004) and highly anticorrelated to NAO after 2005, and (2) small linear cells $(\mathrm{T} 1 \ln \mathrm{Tx})$ were anticorrelated to NAO. Thus, functional groups are better explained by climatic indices than physical factors even if this relation is complex. These observations are particularly interesting considering that detecting the occurrence of toxins-producing species is a public health preoccupation for shellfish consumption and thus economical activities of coastal ecosystems. This revealed that climate might strongly influence the presence of toxic species and thus act in synergism with other anthropogenic pressures to alter the state and 
734 functioning of biological and ecological systems and the services they provide (Goberville et al., 2010).

\subsection{Specific versus functional diversity: what can we expect from such approach?}

Even if warmer years would favor oyster recruitment through favoring the development of small and solitary cells, no direct physical factor seemed to explain the proliferation of small and potentially toxic cells that also impact significantly on oyster recruitment. This functional group had nevertheless been correlated with climatic indices even if these correlations evolved over time (high correlation with either AMO or NAO according to the temporal period considered). The harmful algae recorded in the functional group T1sTx are dependent on different environmental factors: Karenia mikimotoi and Karlodinium are typically marine species blooming during summer (Hall et al., 2008; Zhang et al., 2009) whereas Prorocentrum spp. is an estuarine species developing during spring-summer (Heil et al., 2005). This remark can be extended to all the other functional groups, explaining why none of them appears as specialist in one geographical area. Indicator species provide information about the characteristics of the different geographical areas thanks to their own functional traits (habitat, sensitivity to nutrients, turbulence, etc.) whereas functional groups defined on the basis of oyster requirement for feeding can allow understanding the relationships between prey assemblages and predator. The functional approach based on the morphological and physiological trait proposed by (Smayda and Reynolds, 2001) -S/V ratio and maximum linear dimension would allow to divide the species according to the C-,S-, R- strategies in relation to nutrient availability and turbulence, and would provide more similar results concerning the geographical typology of phytoplankton than specific diversity. Both functional approaches bring very interesting and informative elements for the understanding of the system; the first one concerning the relationships between oyster recruitment, prey assemblage and the complexity of their relation with the environment and the second one on the physical factors driving the phytoplankton community.

Consequently, the choice of functional trait in a functional approach is really important in these kind of studies. Unfortunately, the first criteria in the choice of functional traits implied in the building of functional groups are often the knowledge availability instead of the real adequacy to the objectives of the study or the considered system even if different authors have 
765 proposed some reviews on the different possible and available functional traits of

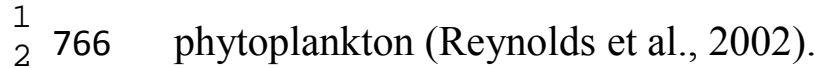

3767

4767

5

6

7

8

9

10

11

12

13

14

15

16

17

18

19

20

21

22

23

24

25

26

27

28

29

30

31

32

33

34

35

36

37

38

39

40

41

42

43

44

45

46

47

48

49

50

51

52

53

54

55

56

57

58

59

60

61

62

63

64

65 


\section{Acknowledgements}

1

2

769 The authors are thankful to the REPHY program and the Ifremer coastal laboratories 770 responsible for water sample and phytoplankton collection. Many thanks to Alliet Convenant 771 and Aurélie Legendre (Ifremer LER/FBN), Dominique Baud-Ratiskol (Ifremer LER/MPL) and 772 Christophe Arnaud (CNRS, UMR LIENSs), Sylvie Genauzeau and Anne Schmitt (Ifremer 773 LER/PC) and Nadine Neaud (Ifremer LER/AR) for phytoplankton identification. We also want 774 to thank Dan Baird for the very constructive corrections given for this manuscript. This study 775 was supported by the French National Programme for Coastal Environment (PNEC) 776 „COMPECO“ coordinated by Nathalie Niquil. 


\section{BIBLIOGRAPHIE}

Adolf, J.E., Bachvaroff, T., Place, A.R., 2008. Can cryptophyte abundance trigger toxic Karlodinium veneficum blooms in eutrophic estuaries? Harmful Algae 8, 119-128.

Alpine, A.E., Cloern, J.E., 1992. Trophic interactions and direct physical effects control phytoplankton biomass and production in an estuary. Limnology and Oceanography 37, 946-955.

Alves-de-Souza, C., Gonzalez, M.T., Iriarte, J.L., 2008. Functional groups in marine phytoplankton assemblages dominated by diatoms in fjords of southern Chile. Journal of Plankton Research 30, 1233-1243.

Anderson, T.R., 2005. Plankton functional type modelling: running before we can walk? Journal of Plankton Research 27, 1073-1081.

Azemar, F., Bouletreau, S., Lionard, M., Muylaert, K., Vyverman, W., Meire, P., Tackx, M., 2007. Looking for general trends in trophic interactions among estuarine micro- and mesozooplankton. Journal of Plankton Research 29, i135-i147.

Baldwin, B.S., Newell, R.I.E., 1995. Feeding rate responses of oyster larvae (Crassostrea virginica) to seston quantity and composition. Journal of Experimental Marine Biology and Ecology 189, 77-91.

Baldwin, B.S., Newell, R.I.E., Jones, T.W., 1989. Omnivorous feeding by Crassostrea virginica larvae : a consumption of naturally occurring phytoplankton, protozoa and bacteria. Journal of Fisheries Research 8, 473.

Barillé, L., Haure, J., Pales-Espinosa, E., Morançais, M., 2003. Finding new diatoms for intensive rearing of the pacific oyster (Crassostrea gigas): energy budget as a selective tool. Aquaculture 217, 501-514.

Barillé, L., Prou, J., Héral, M., Bourgrier, S., 1993. No influence of food quality, but rationdependent retention efficiencies in the Japanese oyster Crassostrea gigas. Journal of Experimental Marine Biology and Ecology 171, 91-106.

Barillé, L., Prou, J., Héral, M., Razet, D., 1997. Effects of high natural seston concentrations on the feeding, selection, and absorption of the oyster Crassostrea gigas (Thunberg). Journal of Experimental Marine Biology and Ecology 212, 149-172.

Beaugrand, G., 2005. Monitoring pelagic ecosystems using plankton indicators. ICES Journal of Marine Science 62, 333-338.

Beaugrand, G., 2009. Decadal changes in climate and ecosystems in the North Atlantic Ocean and adjacent seas. Deep Sea Research Part II: Topical Studies in Oceanography 56, 656673. 
Beaugrand, G., Brander, K.M., Lindley, J.A., Souissi, S., Reid, P.C., 2003. Plankton effect on cod recruitment in the North Sea. Nature 426, 661-664.

Beaugrand, G., Ibañez, F., Lindley, J.A., Reid, P.C., 2002. Diversity of calanoid copepods in the North Atlantic and adjacent seas: Species associations and biogeography. Marine Ecology Progress Series 232, 179-195.

Beaugrand, G., Reid, P.C., 2003. Long-term changes in phytoplankton, zooplankton and salmon related to climate. Global change biology 9, 801-817.

Beliaeff, B., Gros, P., Belin, C., Raffin, B., Gailhard, I., Durbec, J.-P., 2001. „Phytoplankton events" in French coastal waters during 1987-1997. Oceanologica Acta 24, 425-433.

Boström, C., O'Brien, K., Roos, C., Ekebom, J., 2006. Environmental variables explaining structural and functional diversity of seagrass macrofauna in an archipelago landscape. Journal of Experimental Marine Biology and Ecology 335, 52-73.

Bourlès, Y., Alunno-Bruscia, M., Pouvreau, S., Tollu, G., Leguay, D., Arnaud, C., Goulletquer, P., Kooijman, S.A.L.M., 2009. Modelling growth and reproduction of the Pacific oyster Crassostrea gigas: Advances in the oyster-DEB model through application to a coastal pond. Journal of Sea Research 62, 62-71.

Boyce, D.G., Lewis, M.R., Worm, B., 2010. Global phytoplankton decline over the past century. Nature 466, 591-596.

Brown, M.R., McCausland, M.A., Kowalski, K., 1998. The nutritional value of four Australian microalgal strains fed to Pacific oyster Crassostrea gigas spat. Aquaculture 165, 281293.

Carpenter, S.R., Brock, W.A., 2006. Rising variance: a leading indicator of ecological transition. Ecology Letters 9, 311-318.

Cheung, W.W.L., Lam, V.W.Y., Sarmiento, J.L., Kearney, K., Watson, R., Zeller, D., Pauly, D., 2010. Large-scale redistribution of maximum fisheries catch potential in the global ocean under climate change. Global change biology 16, 24-35.

Cloern, J.E., Dufford, R., 2005. Phytoplankton community ecology: principles applied in San Francisco Bay. Marine Ecology Progress Series 285, 11:28.

David, V., Sautour, B., Chardy, P., 2007. The paradox between the long-term decrease of egg mass size of the calanoid copepod Eurytemora affinis and its long-term constant abundance in a highly turbid estuary (Gironde estuary, France). Journal of Plankton Research 29, 377-389. 
David, V., Sautour, B., Chardy, P., Leconte, M., 2005. Long-term changes of the zooplankton variability in a turbid environment: The Gironde estuary (France). Estuarine, Coastal and Shelf Science 64, 171-184.

Delmas, D., Herbland, A., Maestrini, S., 1992. Environmental conditions which lead to increase in cell density of the toxic dinoflagellates Dinophysis spp. in nutrient-rich and nutrientpoor waters of the Atlantic Coast. Marine Ecology Progress Series 89, 53-61.

Dickson, R.R., Turrell, W.R., 2000. The NAO: the dominant atmospheric process affecting oceanic variability in home, middle and distant waters of European Atlantic salmon, in: D, M. (Ed.), The ocean life of Atlantic salmon: environmental and biological factors influencing survival. Fishing News Books, Bodmin, pp. 92-115.

Doney, S.C., 2006. Oceanography: Plankton in a warmer world. Nature 444, 695-696.

Downing, A.L., Leibold, M.A., 2002. Ecosystem consequences of species richness and composition in pond food webs. Nature 416, 837-841.

Dufrêne, M., Legendre, P., 1997. Species assemblages and indicator species: the need for a flexible asymmetrical approach. Ecological Monographs 67, 345:366.

Durieux, E.D.H., M.-L., B., P., P., Sasal, P., 2010. Digenean metacercariae parasites as natural tags of habitat use by 0-group common sole Solea solea in nearshore coastal areas: A case study in the embayed system of the Pertuis Charentais (Bay of Biscay, France). Journal of Sea Research 64, 107-117.

Edwards, M., Reid, P., Planque, B., 2001. Long-term and regional variability of phytoplankton biomass in the Northeast Atlantic (1960-1995). ICES Journal of Marine Science 58, 3949.

Enfield, D.B., Mestas-Nuñez, A.M., Trimble, P.J., 2001. The Atlantic Multidecadal Oscillation and its relationship to rainfall and river flows in the continental U.S. Geophysical Research Letters 28, 2077-2080.

Estrada, M., Varela, R.A., Salat, J., Cruzado, A., Arias, E., 1999. Spatio-temporal variability of the winter phytoplankton distribution across the Catalan and North Balearic fronts (NW Mediterranean). Journal of Plankton Research 21, 1-20.

Fromentin, J., Planque, B., 1996. Calanus and environment in the eastern North Atlantic. II. Influence of the North Atlantic Oscillation on C. finmarchicus and C. helgolandicus. Marine Ecology Progress Series 134, 111-118.

Gailhard, I., Durbec, J.-P., Beliaeff, B., Sabatier, R., 2003. Écologie du phytoplancton sur les côtes françaises : comparaison inter-sites. Comptes Rendus de Biologies 326, 853-863. 
Glé, C., Del Amo, Y., Sautour, B., Laborde, P., Chardy, P., 2008. Variability of nutrients and phytoplankton primary production in a shallow macrotidal coastal ecosystem (Arcachon Bay, France). Estuarine, Coastal and Shelf Science 76, 642-656.

Goberville, E., Beaugrand, G., Sautour, B., Treguer, P., Team, S., 2010. Climate-driven changes in coastal marine systems of western Europe. Marine Ecology Progress Series 208, 129-147.

Gosselin, F., 2006. An assessment of the dependence of evenness indices on species richness. Journal of Theoretical Biology 242, 591-597.

Goulletquer, P., Le Moine, O., 2002. Shellfish farming and coastal zone management (CZM) development in the Marennes-Oléron Bay and Charentais Sounds (Charente Maritime, France): a review of recent development. Aquaculture International 10, 507-525.

Griffiths, S.P., Young, J.W., Lansdell, M.J., Campbell, R.A., Hampton, J., Hoyle, S.D., Langley, A., Bromhead, D., Hinton, M.G., 2010. Ecological effects of longline fishing and climate change on the pelagic ecosystem off eastern Australia, Reviews in Fish Biology and Fisheries, pp. 1-34.

Grosjean, P., Ibanez, F., 2002. Package for analysis of space-time ecological series. PASTECS version 1. 1-1 for R v. 1.6.0, version 1.0-1 for SC2000 rel 3.

Guarini, J.-M., Sari, N., Moritz, C., 2008. Modelling the dynamics of the microalgal biomass in semi-enclosed shallow-water ecosystems. Ecological Modelling 211, 267-278.

Guerrero, F., Rodriguez, V., 1998. Existence and significance of Acartia grani resting eggs (Copepoda: Calanoida) in sediments of a coastal station in the Alboran Sea (SE Spain). Journal of Plankton Research 20, 305-314.

Hall, N.S., Litaker, R.W., Fensin, E., Adolf, J.E., Bowers, H.A., Place, A.R., Paerl, H.W., 2008. Environmental Factors Contributing to the Development and Demise of a Toxic Dinoflagellate (Karlodinium veneficum) Bloom in a Shallow, Eutrophic, Lagoonal Estuary. Estuaries and Coasts 31, 402-418.

Heil, C.A., Glibert, P.M., Fan, C., 2005. Prorocentrum minimum (Pavillard) Schiller: A review of a harmful algal bloom species of growing worldwide importance. Harmful Algae 4, 449-470.

His, E., Robert, R., Dinet, M.J., 1989. Combined effects of temperature and salinity on fed and starved larvae of the Mediterranean mussel Mytilus galloprovincialis and the Japanese oyster Crassostrea gigas. Marine Biology 100, 455-463. 
His, E., Seaman, M.N.L., 1992. Effects of temporary starvation on the survival, and on subsequent feeding and growth of oyster (Crassostrea gigas) larvae. Marine Biology $114,277-279$.

Hurrell, J.W., 1995. Decadal trends in the North Atlantic Oscillation: regional temperatures and precipitations. Science 269, 676-679.

Ibanez, F., Dauvin, J.-C., Etienne, M., 1993. Comparaison des evolutions a long terme (19771990) de deux peuplements macrobenthiques de la baie de Morlaix (Manche occidentale): relations avec les facteurs hydroclimatiques. Journal of Experimental Marine Biology and Ecology 169, 181-214.

Jouenne, F., Lefebvre, S., Véron, B., Lagadeuc, Y., 2007. Phytoplankton community structure and primary production in small intertidal estuarine-bay ecosystem (eastern English Channel, France). Marine Biology 151, 805-825.

Kaneta, P.J., Levandowsky, M., Esaias, W., 1985. Multivariate analysis of the phytoplankton community in the New York Bight. Marine Ecology Progress Series 23, 231-239.

Karentz, D., Smayda, T.J., 1984. Temperature and seasonal occurrence patterns of 30 dominant phytoplankton species in Narragansett Bay over a 22-year period (1959-1980). Marine Ecology Progress Series 18, 277-293.

Kroonenberg, P.M., 1989. The analysis of multiple tables in factorial ecology. III. Three-mode principal component analysis: ,,,analyse triadique complète ${ }^{\text {eee }}$. Acta Oecologica 10, 245 256.

Kruk, C., Mazzeo, N., Lacerot, G., Reynolds, C.S., 2002. Classification schemes for phytoplankton: a local validation of a functional approach to the analysis of species temporal replacement. Journal of Plankton Research 24, 901-912.

Labry, C., Herbland, A., Delmas, D., Laborde, P., Lazure, P., Froidefond, J.M., Jegou, A.M., Santour, B., 2001. Initiation of winter phytoplankton blooms within the Gironde plume waters in the Bay of Biscay. Marine Ecology Progress Series 212, 117-130.

Lazure, P., Jegou, A.-M., 1998. 3D modelling of seasonal evolution of Loire and Gironde plumes on Biscay Bay continental shelf. Oceanologica Acta 21, 165-177.

Leterme, S.C., Pingree, R.D., Skogen, M.D., Seuront, L., Reid, P.C., Attrill, M.J., 2008. Decadal fluctuations in North Atlantic water inflow in the North Sea between 19582003: impacts on temperature and phytoplankton populations. Oceanologia 50, 59-72.

Leverone, J.R., Blake, N.J., Pierce, R.H., Shumway, S.E., 2006. Effects of the dinoflagellate Karenia brevis on larval development in three species of bivalve mollusc from Florida. Toxicon 48, 75-84. 
Llope, M., Daskalov, G.M., Rouyer, T.A., Mihneva, V., Chan, K.S., Grishin, A.N., Stenseth, N.C.H.R., 2011. Overfishing of top predators eroded the resilience of the Black Sea system regardless of the climate and anthropogenic conditions. Global change biology $17,1251-1265$.

Margalef, R., 1978. Life forms of phytoplankton as survival alternatives in an unstable environment. Oceanologica Acta 1, 493-509.

McQuoid, M.R., Godhe, A., Nordberg, K., 2002. Viability of phytoplankton resting stages in the sediments of a coastal Swedish fjord. European Journal of Phycology 37, 191-201.

Munk, P., 1997. Prey size spectra and prey availability of larval and small juvenile cod. Journal of Fish Biology 51(Suppl A), 340-351.

Olenina, I., Haldu, S., Edler, L., Andersson, A., Wasmund, N., Busch, S., Gobel, J., Gromiscz, S., Huseby, S., Huttunen, M., Jaanus, A., Kokkonen, P., Ledaine, I., Niemkiewicz, E., 2006. Biovolumes and size-classes of phytoplankton in the Baltic Sea, Helsinky.

Olson, R.R., Olson, M.H., 1989. Food limitation of planktotrophic marine invertebrate larvae : does it control recruitment success. Annual Review of Ecology, Evolution and Systematics 20, 225-247.

Pasquaud, S., David, V., Lobry, J., Girardin, M., Sautour, B., Elie, P., 2010. Exploitation of trophic resources by fish under stressful estuarine conditions. Marine Ecology Progress Series 400, 207-219.

Penna, A., Vila, M., Fraga, S., Giacobbe, M.G., Francesco, A., Riobó, P., Vernesi, C., 2005. Characterization of Ostreopsis and Coolia (Dinophyceae) isolates in the western Mediterranean Sea based on morphology, toxicity and internal transcribed spacer $5.8 \mathrm{~s}$ rDNA sequences. Journal of Phycology 41, 212-225.

Raby, D., Mingelbier, M., Dodson, J.J., Klein, B., Lagadeuc, Y., Legendre, L., 1997. Foodparticle size and selection by bivalve larvae in a temperate embayment. Marine Biology $127,665-672$.

Raymont, E.G., 1980. Plankton and productivity in the oceans. Vol 1. Phytoplankton, in: Press, P. (Ed.), Oxford, p. 489.

Reid, P.C., Lancelot, C., Gieskes, W.W.C., Hagmeieir, E., Weichart, G., 1990. Phytoplankton of the North Sea and its dynamics: a review. Netherland Journal of Sea Research 26, 295-331.

Reynolds, C.S., Huszar, V., Kruk, C., 2002. Towards a functional classification of the freshwater phytoplankton. Journal of Plankton Research 24, 417-428. 
Richardson, A., Schoeman, D.S., 2004. Climate Impact on Plankton Ecosystems in the Northeast Atlantic. Science 305, 1609-1612.

Rico-Villa, B., Le Coz, J.R., Mingant, C., Robert, R., 2006. Influence of phytoplankton diet mixtures on microalgae consumption, larval development and settlement of the Pacific oyster Crassostrea gigas (Thunberg). Aquaculture 256, 377-388.

Robert, R., 2003. Microalgae as food for molluscs, in: Ed., J.G.S.L.A.M. (Ed.), live feeds in marine aquaculture. Blackwell Publishing, pp. 254-263.

Robert, R., Trintingnac, P., 1997. Substitues for live microalgae in mariculture: a review. Aquatic Marine Resources 10, 315-327.

Roemmich, D., McGowan, J., 1995. Climatic Warming and the Decline of Zooplankton in the California Current Science 267, 1324-1326.

Rollo, N., Robin, M., 2010. Relevance of watershed modelling to assess the contamination of coastal waters due to land-based sources and activities. Estuarine, Coastal and Shelf Science 86, 518-525.

Roussel, E., Crec'hriou, R., Lenfant, P., Mader, J., Planes, S., 2010. Relative influences of space, time and environment on coastal ichthyoplankton assemblages along a temperate rocky shore. Journal of Plankton Research doi: 10.1093/plankt/fbq056.

Ryckaert, M., Gros, P., Erard-Le Denn, E., 1983. Seasonal succession of coastal phytoplanctonic populations in the Channel. Oceanologica Acta Special issue, 171-175.

Scholtz, A.J., Cooke, W.A., Cooper, K.L., Donaldson, J., 1984. Beach setting of eyed oyster larvae Crassostrea gigas (Thunberg) in Puget sound Washington., NSA West Coast Section Meeting, Belhingham, Washington, Sept 7-8 1984, p. 53.

Smayda, T.J., Reynolds, C.S., 2001. Community assembly in marine phytoplankton: application of recent models to harmful dinoflagellate blooms. Journal of Plankton Research 23, 447-461.

Smayda, T.J., Reynolds, C.S., 2003. Strategies of marine dinoflagellate survival and some rules of assembly. Journal of Sea Research 49, 95-106.

Soletchnik, P., Ropert, M., Mazurié, J., Gildas Fleury, P., Le Coz, F., 2007. Relationships between oyster mortality patterns and environmental data from monitoring databases along the coasts of France. Aquaculture 271, 384-400.

Thioulouse, J., Simier, M., Chessel, D., 2004. Simultaneous analysis of a sequence of paired ecological tables. Ecology 85, 272-283.

Thomas, W.H., Gibson, C.H., 1990. Effects of small-scale turbulence on microalgae. Journal of Applied Phycology 2, 71-77. 
1009

1

$2^{1010}$

${ }_{4}^{3} 1011$

51012

71013

8

91014 10

111015

12

$13^{1016}$

141017

161018

17

181019

19

201020

21

221021

23

241022

25

26

271024

28

291025

30

311026

32

331027

34

35

36

37

38

39

40

41

42

43

44

45

46

47

48

49

50

51

52

53

54

55

56

57

58

59

60

61

62

63

64

65

Tilman, D., Knops, J., Wedin, D., Ritchie, M., Siemann, E., 1997. The influence of functional diversity and composition on ecosystem processes. Science 29, 1300-1302.

Utermohl, H., 1958. Zur Vervollkommnung der quantitativen Phytoplankton-Methodik. Mitteilungen Internationale Vereinigung Theoretische und Angewandte Limnologie 9, $1-38$.

Washington, H.G., 1984. Diversity, biotic and similarity indices: A review with special relevance to aquatic ecosystems. Water Research 18, 653-694.

Wikfors, G.H., 2005. A review and new analysis of trophic interactions between Prorocentrum minimum and clams, scallops, and oysters. Harmful Algae 4, 585-592.

Wilson, S.K., Fisher, R., Pratchett, M.S., Graham, N.A.J., Dulvy, N.K., Turner, R.A., Cakacaka, A., Polunin, N.V.C., Rushton, S.P., 2008. Exploitation and habitat degradation as agents of change within coral reef fish communities. Global change biology 14, 2796-2809.

Wollenberg, A.L., 1977. Redundancy analysis, an alternative for canonical analysis. Psychometrika 42, 207-219.

Zhang, F., Ma, L., Xu, Z., Zheng, J., Shi, Y., Lu, Y., Miao, Y., 2009. Sensitive and rapid detection of Karenia mikimotoi (Dinophyceae) by loop-mediated isothermal amplification. Harmful Algae 8, 839-842. 


\section{FIGURES CAPTIONS}

Figure 1: Geographical distribution of the 8 stations along the Atlantic Coast. These stations are localized on 4 geographical zones from North to South: North Brittany (Saint Cast, Paimpol), South Brittany (Le Croisic), Pertuis Charentais (Eperon, Cornard, Boyard, Auger) and Arcachon Bay (Arcachon).

Figure 2: Diagram of the analysis steps

Figure 3: Redundancy analysis of interannual variability of the eight stations along the Atlantic Coast based on species abundances for axis 2 vs axis 1 (A-C) and Axis 3 vs Axis 1(D-F). Environmental variables (physical factors and climate indices, A and D), observations (B and E) and species abundances $(\mathrm{C}$ and $\mathrm{F})$.

Figure 4: Redundancy analysis of interannual variability of the eight stations along the Atlantic Coast based on functional groups abundances for axis 2 vs axis 1. Environmental variables (A), observations (B) and functional group abundances (C).

Figure 5: Indicator taxa (A) or functional groups (B) for each hierarchical level of cluster established according the similarity between geographical areas. IndVal values are shown in brackets. Only the highest IndVal values for each taxon were reported at each hierarchical level (IndVal bold values indicate the highest IndVal values).

Figure 6: Partial triadic analysis on interannual variability of the four stations sampled between 1993 and 2010 based on species abundances (,specific diversity ${ }^{e e}$, left) and functional-groups abundances (,functional diversitye, right). First factorial plan of the compromise for the environmental variables ( $\mathrm{A}$ and $\mathrm{D}$, respectively); First factorial plan of the compromise for the date points (grey continuous lines for the SB station -Le Croisic-, black continuous line for Eperon, large dotted line for Le Cornard and thin dotted line for Boyard) (B and E, respectively, years were reported on the figure); First factorial plan of the compromise (C and F, respectively).

Table 1: Phytoplanktonic functional groups defined according to important functional traits for oyster feeding. 


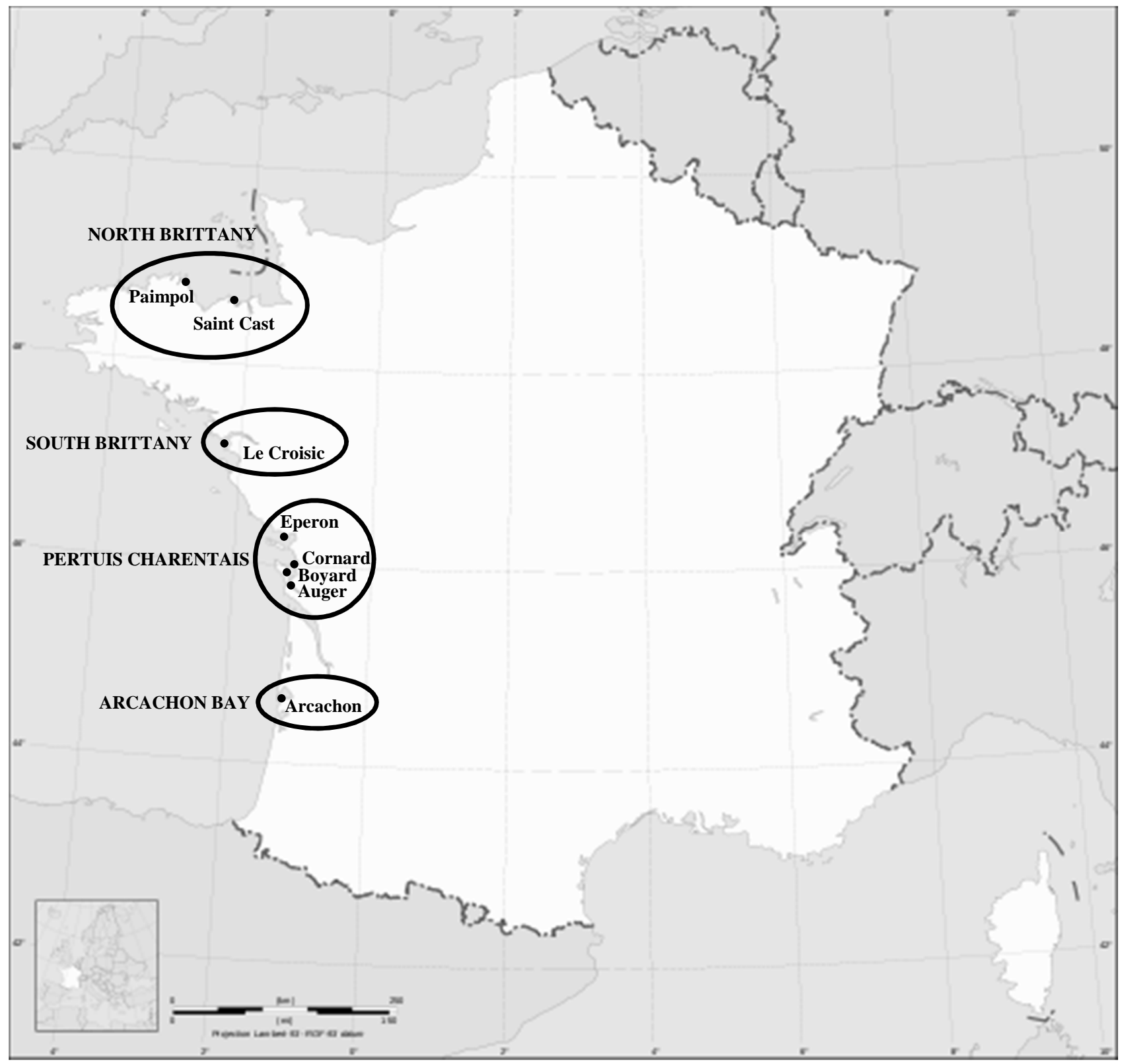


Microphytoplankton database (abundances of 358 taxa) $\times$ stations $(8) \times$ time $(214,349$ or 595 dates) Physical datab ase (Temperature, Salinity, Turbidity) $\times$ stations $(8) \times$ time $(214,349$ or 595 dates $)$

Rare species elimination (Abundance sorting method)

Data regularisation (spline method, lag $=15$ days)

Repartition of the taxa in functional groups $(\mathrm{FG})$ according to their availability for oysters (4 functional traits)

Specific database (106 taxa)

Functional database ( 10 functional groups)

Physical database (Temperature, Salinity, Turbidity) $\times$ stations $(8) \times$ time $(168,268$ or 409 dates $)$ Climatic indices (NAO, AMO)

Extraction of the interannual variability (moving average -24 data per year)

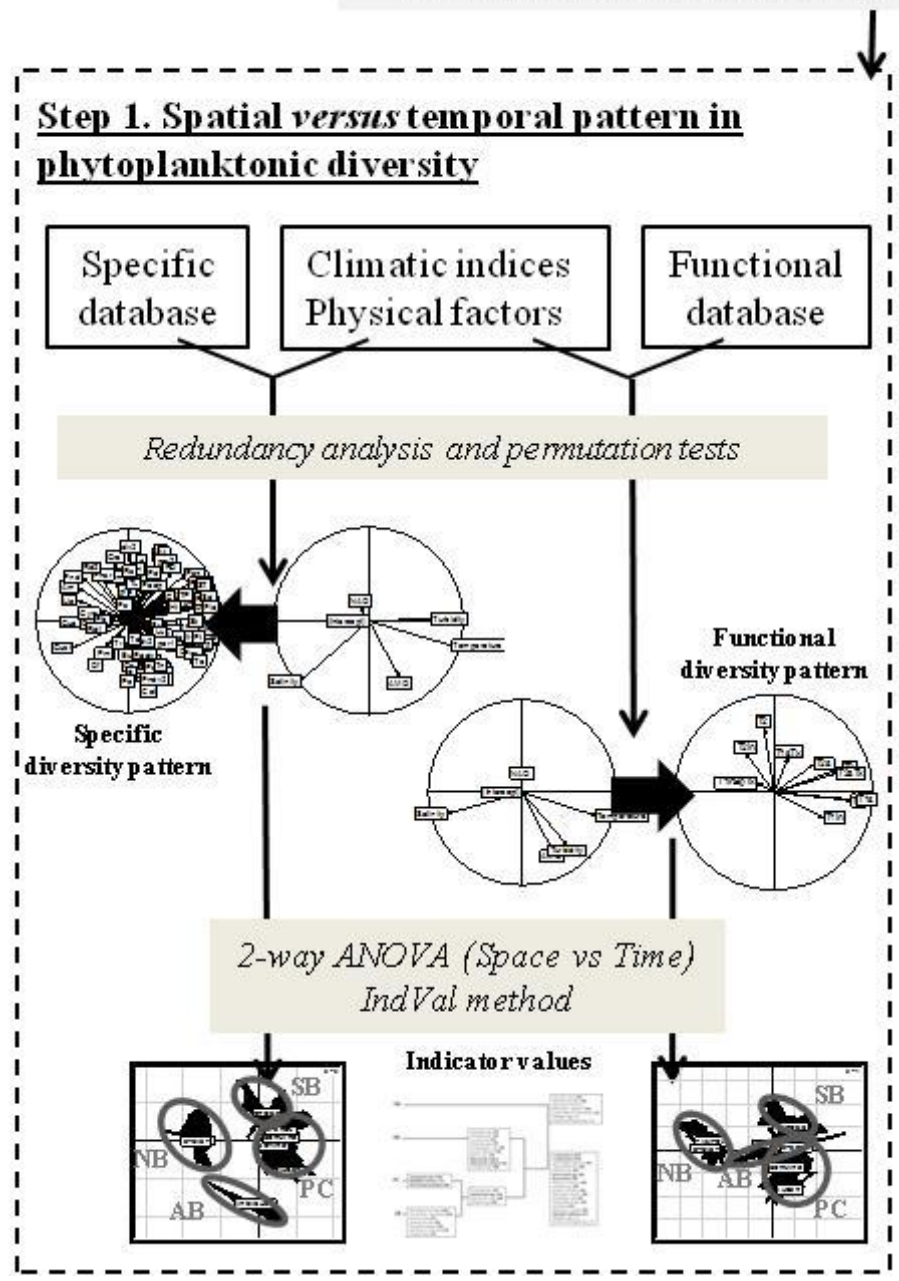

Step 2. Temporal variation related to physical factors and climaticindices

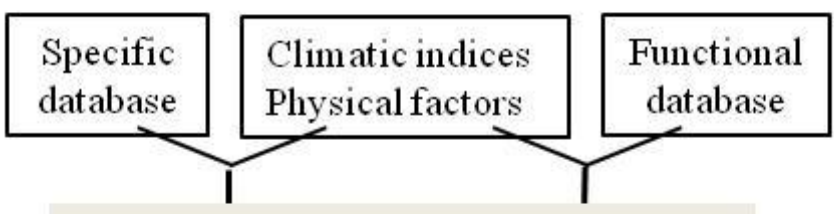

Partial triadic analysis for 3 periods

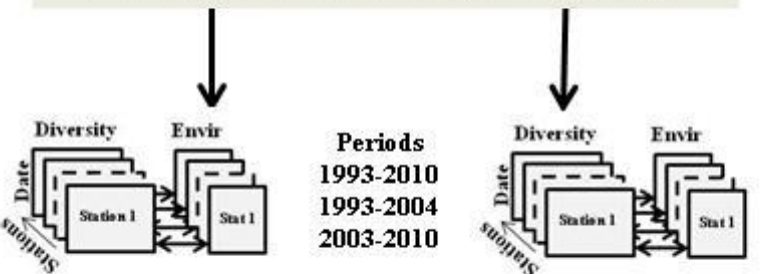
003-2010 

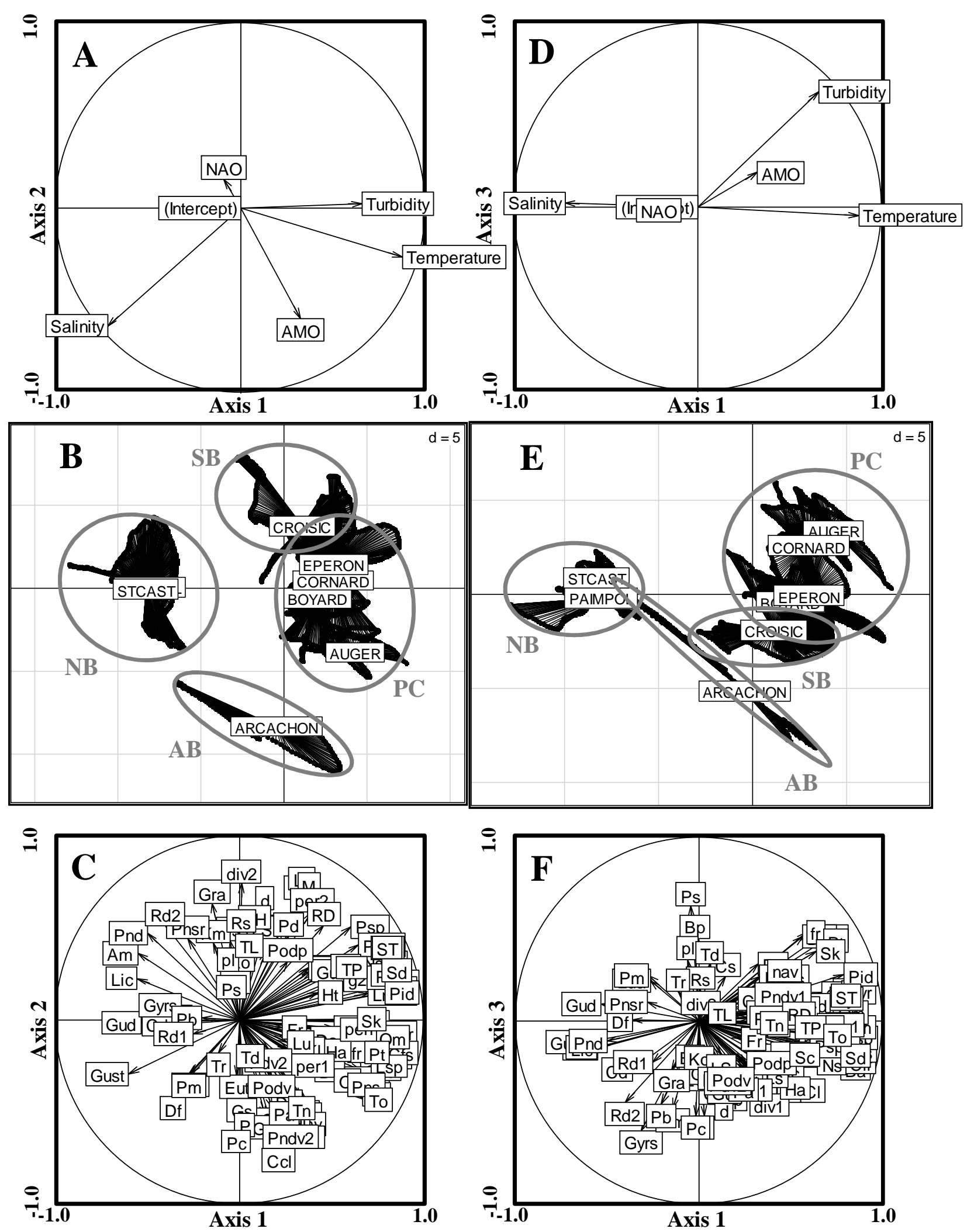

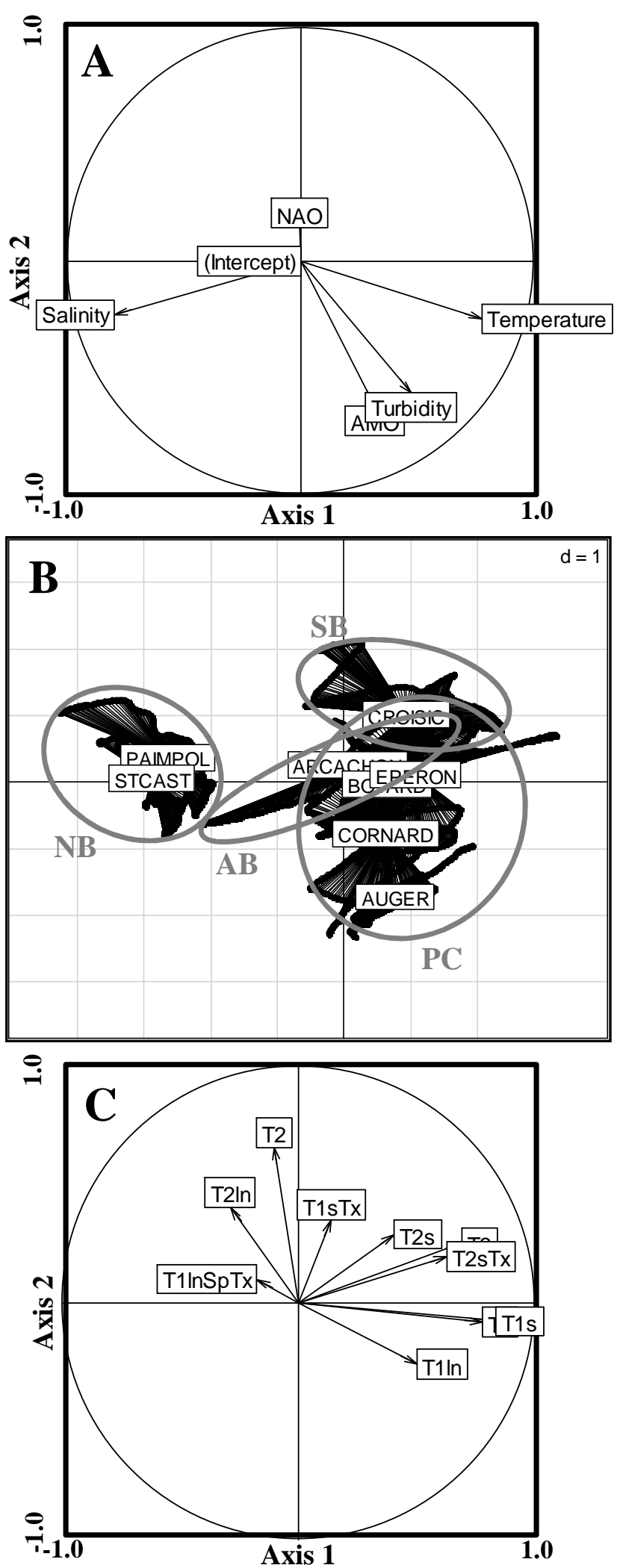


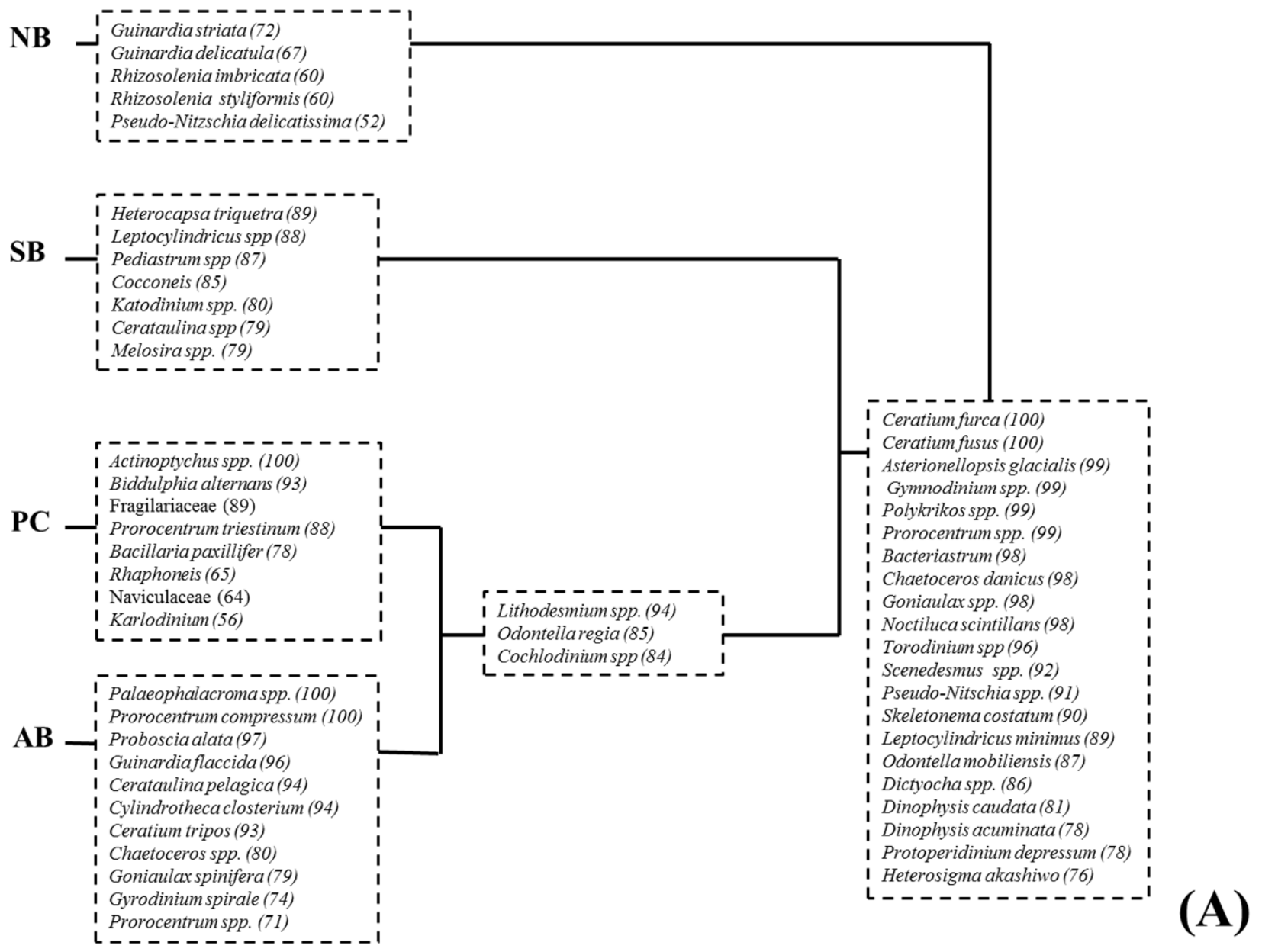

NB $\left\{\begin{array}{l}T 2 s(44) \\ T 2 \ln (61) \\ \mathbf{I}-\mathbf{i}\end{array}\right.$

SB $\begin{aligned} & \mathbf{r} T 1 s T x(79) \\ & T 2(83) \\ & ----\ldots\end{aligned}$

$\mathrm{PC} \longrightarrow \frac{\mathrm{NA}}{---}$

AB 

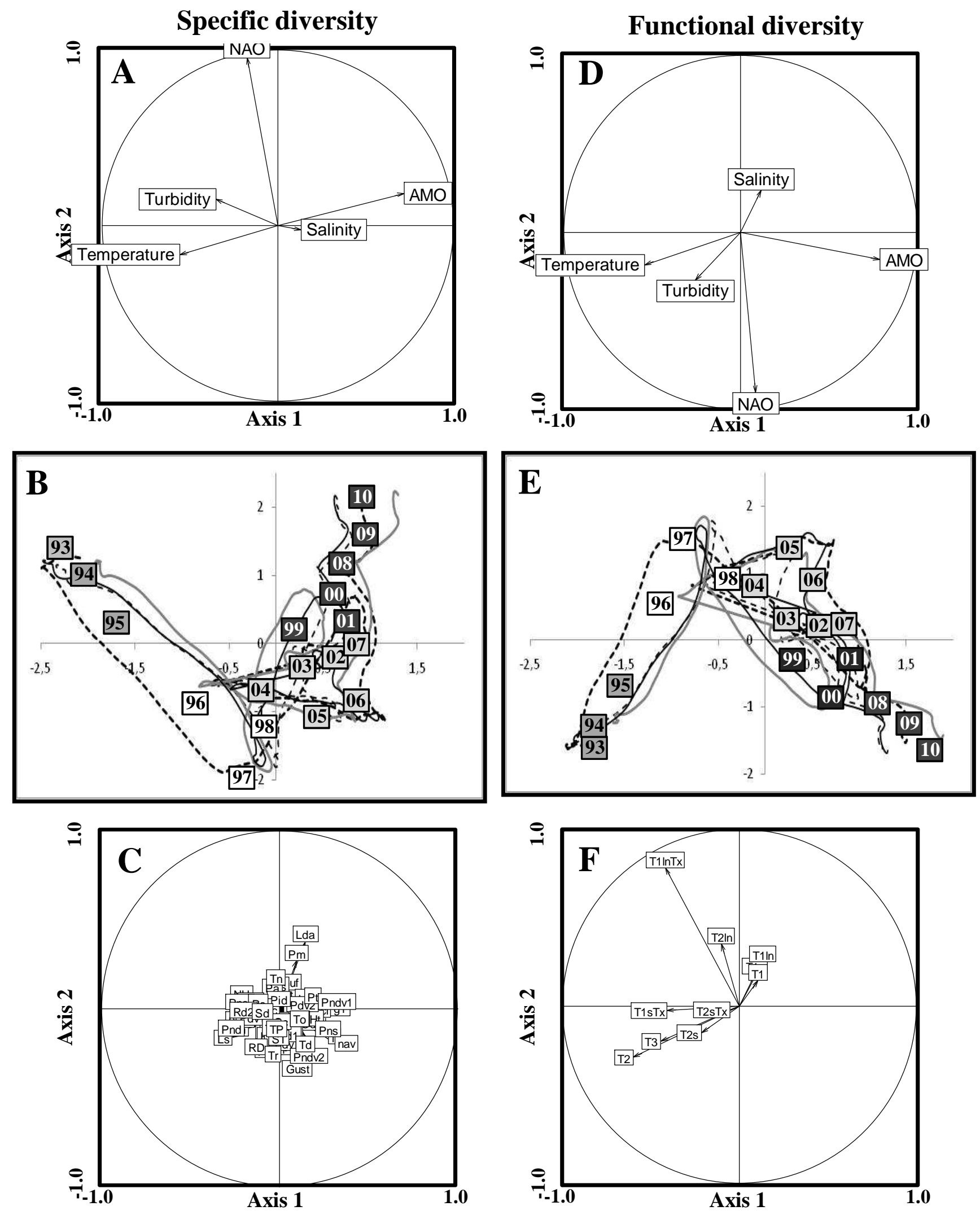


\section{TABLE 1}

\begin{tabular}{lll}
\hline Codes & Functional traits & Examples \\
\hline T1s & Small size / solitary / no spines /non toxic & $\begin{array}{l}\text { Scenedesmus } \\
\text { Naviculaceae }\end{array}$ \\
\hline T1sTx & Small size / solitary / no spines / potentially & Karlodinium spp., \\
& toxic & Karenia mikimotoi \\
\hline T1ln & Small size / linear colony / no spines non & Thalassionema \\
& toxic & nitzschioides \\
\hline T1InSpTx & Small size / linear colony with spines or & Pseudo-nitzschia \\
& pointed tips / potentially toxic & \\
\hline T1 & Small size / others & Cylindrotheca closterium \\
\hline T2s & Median size / solitary / no spines /non toxic & Rhizosolenia styliformis \\
& & Katodinium spp. \\
\hline T2sTx & Median size / solitary / no spines $/$ & Dinophysis caudata \\
& potentially toxic & \\
\hline T2ln & Median size / linear colony / no spines non & Guinardia striata \\
\hline T2 & toxic & \\
\hline T3 & Median size / others & Rhizosolenia \\
\hline & Large size & Noctiluca scintillans \\
\hline
\end{tabular}

